\title{
Banks as Catalysts for Industrialization
}

\author{
By: Marco Da Rin and Thomas Hellmann
}

William Davidson Working Paper Number 443

October 2001 


\title{
Banks as Catalysts for Industrialization
}

\author{
Marco Da Rin* \\ Università di Torino and IGIER \\ and \\ Thomas Hellmann \\ G.S.B. - Stanford University
}

October 2001

\begin{abstract}
We provide a new theory of the role of banks as catalysts for industrialization. In their influential analysis of 19th century continental European industrialization, Gerschenkron and Schumpeter accorded banks a central role, arguing that they promoted the creation of new industries. We formalize this role of banks by introducing financial intermediaries into a 'big push' model. We show that banks may act as 'catalysts' for industrialization provided that they are sufficiently large to mobilize a critical mass of firms, and that they possess sufficient market power to make profits from coordination. The theory provides simple conditions that help to explain why banks seem to play a creative role in some but not in other emerging markets. The model also shows that universal banking helps to reduce the cost of coordination. Finally, we show that one disadvantage of catalytic banks is that they may favor concentration in the industrial sector.
\end{abstract}

\footnotetext{
${ }^{*}$ We would like to thank Masahiko Aoki, Ashish Arora, Giuseppe Bertola, Sugato Bhattacharya, Marcello De Cecco, Klaus Desmet, Serdar Dinç, Marcel Fafchamps, Avner Greif, Dietmar Harhoff, Ross Levine, Manju Puri, Rafael Repullo, John Roberts, Andrés Rodríguez-Clare, Javier Suarez and an anonymous referee for their comments, as well as seminar participants at Bologna, CEMFI (Madrid), the CEPR Alghero Conference on Financial Intermediation, FMG/LSE, IGIER (Università Bocconi), the Journal of Financial Intermediation 2001 Symposium on 'Banking in Emerging Markets,' NBER, Torino, and Stanford. We gratefully acknowledge financial support from the Financial Markets Group at LSE. All errors remain our own.
} 


\section{Introduction}

A significant problem in the study of emerging markets is that there are relatively few data points. It is therefore particularly important to go back in history to learn from all available experiences. Historically, economists accorded great importance to the role of banks in the development of new markets and industries. The influential work of Gerschenkron (1962) and Schumpeter $(1934,1939)$, for example, placed banks at the center of economic growth. Their accounts of the role of banks, however, differ in some important ways from our modern theories of banking, which emphasize the role of banks in screening and monitoring firms. In the modern view, the impetus for economic growth is generated in the real economy, and the banking system provides some important, but ancillary, services. The work of Schumpeter, Gerschenkron and others, however, is somewhat bolder. It accords banks a more active and 'creative' role, where banks are central actors of the real economy who act as catalysts for industrialization and growth. Because this view does not fit well with modern banking theory, it has become almost forgotten. Yet it emerged from a careful study of industrialization in several European countries, that were arguably some of the most successful emerging economies ever. What can a modern day economist make of the notion of banks as catalysts for economic activity?

Gerschenkron related the creative role of banks specifically to the so-called 'catch-up' problem. He argued that the main challenge for achieving rapid economic growth in 19th century continental Europe was coordination of industrial activity. Britain had already pioneered industrialization, and the issue in continental Europe was to mobilize resources to follow its example. Following the seminal work by Murphy, Shleifer and Vishny (1989), a recent literature on 'big push' models has formalized the notion of catch-up economy. This literature, reviewed by Matsuyama (1995a), has focussed on a variety of positive externalities between investments in order to derived the existence of multiple Pareto-rankable equilibria. In the typical model, a low equilibrium is characterized by a self-perpetuating belief that no industrialization occurs, whereas a high equilibrium is sustained by a selffulfilling expectation that industrialization will occur.

While 'big push' models have been used to explain periods of rapid industrialization, it may come as a surprise that the role of banks has not been addressed in this literature. In fact, 'big push' models study the conditions under which an economy may find itself stuck in a low equilibrium, but pay little attention to which institutions may remedy the coordination failure which generates the low equilibrium itself. We are thus left with some

important open questions. Can banks affect the economy-wide equilibrium? What are the theoretical foundations for the role of banks as catalysts for industrialization? What does it mean to create new industries or to be a catalyst for growth? And under what circumstances would banks want to take such an active role in the economy? 
This paper sets out to provide a modern economic understanding of the role of banks as catalysts for industrialization in emerging economies. The paper breaks out into three parts. We want to build a theory that is informed by history. In the first part of the paper we thus review historic evidence that suggests an active role for banks. Based upon the work of Schumpeter, Gerschenkron and others, we provide historic evidence from three continental European countries that experienced periods of rapid industrialization: Belgium from 1830 to 1850 , Germany from 1850 to 1870 and Italy from 1894 to 1914 . We focus on what role banks play in these countries and uncover some interesting common patterns. In each country a small number of banks accounted for the bulk of investments in the industries that generated rapid economic growth. These banks invested in a portfolio of firms that depended on one another and that together pioneered new markets and industries. These banks were also large oligopolists, that held powerful market positions at the beginning of the rapid growth periods. Interestingly, these were also the banks that pioneered universal banking. And as time proceeded, these banks changed their focus from financing new and innovative firms to protecting those incumbent firms by encouraging industrial concentration. These historical facts are clearly important for any economist interested in the role of banks in emerging markets. They also challenge us to provide a clear theoretical explanation.

In the second part of the paper we confront the historic approach with the tools of modern theoretical analysis and develop a new theory of the role of banks in promoting industrialization in emerging economies. Our starting point is a generic 'big push' model where there are two Pareto-rankable equilibria. We ask how a bank can induce the economy to move from the low to the high equilibrium. We show how a bank can mobilize a 'critical mass' of firms, i.e. invest in a set of firms that induces other banks and firms to also invest in the emerging markets. Making such 'catalytic' investments, however, is shown to be costly. A bank will only invest in a critical mass if it expects to recover its losses. This means that in the high equilibrium the bank needs to make profits on some additional firms outside the critical mass. The model then yields two important predictions. Banks will only play a catalytic role if they are sufficiently large to invest in a critical mass of firms. And they need to have enough market power to recoup the costs of mobilizing the critical mass. Next, we show that the costs mobilizing the critical mass are reduced if banks are allowed to own equity. The intuition is that equity allows the banks to participate in the value they create by mobilizing the critical mass. This leads to an additional prediction of the model, that universal banks will find it easier to promote investments in new industries. Moreover, we show that catalytic banks are not immune from disadvantages. In particular, one disadvantage of banking concentration is that it may foster concentration in the industrial sector. More specifically, we show that the number of entrant firms that are financed to compete with an industry incumbent is lower in the presence of large banks. We also 
develop a number of extensions of our model that show the robustness of these predictions.

The third part of the paper takes the theory back to empirical evidence. We examine some additional facts not considered by Gerschenkron and Schumpeter. We look at cases where banks did not play a catalytic role in the industrialization of emerging economies, at political economy issues, and at alternative catalysts for industrialization. We relate this variation in behavior to the predictions of the model. Moreover, we derive further implications that can be formally tested.

We believe we are the first to introduce banks into a model of the 'big push.' This allows us to examine a new role for banks that has received scant attention in the literature: catalyst to ind ustrialization. This role is distinct from the traditional roles attributed to banks, namely the allocation of capital and the screening and monitoring of individual firms (see, for example, Fama (1980), Diamond (1984), and Stiglitz (1985), among others). For an extensive survey of modern theories of banking, see Bhattacharya and Thakor (1993). This catalytic role is also distinct from the literature on relationship banking (see, for example, Allen and Gale (1997), Aoki and Patrick (1994), Dinç (2000), Rajan (1992), and von Thadden (1995)), since we are concerned about the economy-wide effects of the interactions of one bank with many firms at a time, as opposed to the details of the interaction between one bank with one client over time. We thus contribute a distinctly novel 'macro' theory of banking.

A large literature has developed the role of banks in economic development. See, for example, King and Levine (1993), Rajan and Zingales (1998), and especially the survey by Levine (1997). This literature has focussed on the role of financial intermediaries in facilitating exchange and providing liquidity (e.g. Bencivenga and Smith (1991)), and in diversifying risks (e.g. Acemoglu and Zilibotti (1997)), or on comparing banks and stock markets in facilitating economic development (e.g. Levine and Zervos (1998)). Our paper complements this literature by examining the role of banks in coordinating investments. This paper is also related to the literature on the role of venture capital for firm creation and innovation (see Lerner and Merges (1998), Hellmann and Puri (2000, 2002) and Kaplan and Strömberg (2000)). And our theory contributes to the literature on universal banking, surveyed by Benston (1994).

The remainder of the paper is organized as follows. Section 2 provides historical evidence from three formerly emerging continental European countries - Belgium, Germany, and Italy - describing the role of banks in industrialization and linking it to the structure of the financial system. Section 3 develops the theoretical model, examining the conditions under which banks can act as a catalyst for industrialization. Section 4 derives from the model several testable hypotheses and discussess some recent relevant formal tests. It is followed by a brief conclusion. All the proofs are in the Appendix. 


\section{Banks and the industrialization of Belgium, Germany and Italy}

In his seminal work on economic development, Gerschenkron (1962, p.45) wrote that "[t]he focal role in capital provision in a country like Germany must be assigned not to any original capital accumulation but to the role of credit-creation policies on part of the banking system." Rondo Cameron (1967, p.129) wrote about Belgium: "[S] ubsequently [to 1830] the economy entered a period of explosive growth accompanied by the development of a unique set of banking institutions." Schumpeter (1939, chapter 7) gave German Kreditbanken large credit for taking an entrepreneurial attitude and fostering the rise of large industries. These economic historians clearly saw a link between fast industrialization and the financing of industry by private banks. They also pointed out problems stemming from the oligopolistic structure of financial markets. Tilly (1982)) and Riesser (1911, ch.5), for example, note that in the later stages of Germany's industrialization the power of those banks that helped industrialize also led to a certain 'ossification' of both the industrial and banking market structures. Confalonieri (1982) makes a similar point for Italy after 1907 in his conclusions.

In this section we examine historical evidence from the three continental European countries that experienced fast industrialization in the nineteenth century, focusing on the initial stages of their industrialization: Belgium (from 1830 to 1850), Germany (from 1850 to 1870), and Italy (from 1894 to 1914). We devote particular attention to the structure of credit markets, an aspect often alluded to in the debate among economic historians but rarely linked explicitly to the role of banks as industrial promoters. We thus provide a novel perspective from which to look at well known facts. For each country we show that a few large private banks financed the majority of new industrial firms. These banks did not develop as a consequence of industrialization, but pre-existed it. They enjoyed considerable market power in an oligopolistic banking market that was protected by regulatory barriers to entry. They actively promoted investment in industrial technology, and engaged in coordination of industrial investments. These banks acted not only as lenders but also as shareholders, thus pioneering universal banking. And over time, they actively encouraged the cartelization of several industries in order to protect existing firms and the stability of their profits. Moreover these banks were concerned with maintaining the oligopoly among industrial financiers, possibly at the cost of slowing down growth and innovation in the industrial banking sector itself.

\subsection{Belgium}

Belgium, the first country to follow Britain in the Industrial Revolution, achieved its industrialization roughly between 1830 and 1850 . Over this period, its GNP grew at a yearly 
$2.5 \%$, well above the $1.4 \%$ European average. ${ }^{1}$ Industrialization transformed the structure of the economy, which until then was based on small firms engaged in traditional production. Between 1830 and 1860 its industrial capacity grew at a yearly average of $4.4 \%$, more than twice as in the previous thirty years (Bairoch (1982), p.292). Modernization was most intense in the heavy industries. Between 1830 and 1850 coal mining grew at a yearly $5.3 \%$, zinc mining at $20.0 \%$, and steam engines at $7.9 \%{ }^{2}$

Critical to this success was the action of two banks. The Société Générale pour favoriser l'industrie nationale was the world's first joint-stock investment bank. It had been created in 1822, and became active in industrial finance from the early 1830s. The Banque de Belgique was founded in 1835, and engaged in industrial finance from the outset. ${ }^{3}$ These two banks accounted for about two thirds of the capitalization of all industrial credit banks (Durviaux (1947), p.56), ${ }^{4}$ and their assets grew by an average yearly rate of $3.8 \%$ between 1834 and 1850 (Chlepner (1926), p.76-8). These two banks financed themselves mainly with their own capital; until 1850 deposits never accounted for more than $25 \%$ of the liabilities (Durviaux (1947), p.37). Other industrial banks existed, but were smaller and mostly local. ${ }^{5}$ Entry of joint stock-banks into the financial sector was restricted, since the government had discretionary power in granting banking charters, according to article 7 of the Code du Commerce (Neuville [1974], p.109-11). Indeed, the Société Générale and the Banque de Belgique faced no competition from incorporated banks.

These two banks assisted and actively encouraged firms in fast growing industries to adopt the corporate form in order to raise large amounts of external finance. ${ }^{6}$ Between 1835 and 1838 alone, the Société Générale organized 31 industrial joint-stock companies (sociétés anonymes), and the Banque de Belgique 24. They also helped these new firms raise a combined capital of 154 million Francs. (Cameron (1967), p.145). The two banks invested a large share of their capital in industrial equity: 31\% for the Société Générale and 26\% for the Banque de Belgique in 1847 (Chlepner (1930), p.26). In 1860, the Société Générale controlled about a fifth of the country's industrial joint-stock capital, which amounted to

\footnotetext{
${ }^{1}$ Bairoch (1976a), p.281-6. In per capita terms these two figures are $1.6 \%$ and $0.8 \%$, respectively.

${ }^{2}$ Cameron (1967), p.148. Railways played a lesser role at this stage of the Belgian industrialization, though in these two decades $850 \mathrm{~km}$ of railroads were built, Mitchell (1980), tab G1.

${ }^{3}$ On the development of the Belgian financial sector see Cameron (1967), Chlepner $(1926,1930,1943)$, Morrison (1967), Société Générale de Belgique (1922), and Wee (1981).

${ }^{4}$ The initial capital of the Société Générale was 33 million Francs, which was doubled in 1837; the initial capital of the Banque fu Belgique was 20 million Francs, Durviaux (1937), p.11.

${ }^{5}$ See Cameron (1967), p.134-6, and Chlepner (1930), p.21-24. At least seven such banks appeared in the late 1830s: The Banque Liégeoise, the Banque Commerciale d'Anvers, the Banque d'Industrie, the Banque de Flandre, the Banque Fonciére, the Caisse Hypotécaire, and the Caisse de Propriétaires, Chlepner (1930), p.61-3.

${ }^{6}$ Six industrial sociétés anonymes (joint-stock companies) existed in 1830, which grew to 150 in 1839 , and to 200 in 1857, Cameron (1967), p.130. Durviaux (1947), p.53, gives a detailed sectoral breakdown, and Neuville [1974], p.113-5, yearly data. See also Morrison (1967), p.64, and Chlepner (1943), p.8-9.
} 
1 billion Francs. ${ }^{7}$ As Cameron (1967, p.145) put it, "banks did not respond passively to demand for credit, but actively sought new firms, underwrote their stock issues, financed potential stockholders, held stock in their own names, placed their officers on the board of directors of the companies they promoted, and ministered to the companies' needs for both working capital and new capital for expansion." These investments turned out to be profitable. The net income of the Société Générale, for instance, which started at a level around $4 \%$ of assets in 1830, increased constantly until 1860 (Société Générale (1922), Annexes).

The Société Générale and the Banque de Belgique were the first examples of universal banks. They identified industries with high potential for growth, to which they extended credit and in which they bought equity participations. ${ }^{8}$ For this purpose they came up with an important innovation, financial trusts. ${ }^{9}$ Financial trusts were holding companies which managed the two banks' industrial portfolios. ${ }^{10}$ This way they enhanced the coordination of investment decisions by otherwise scattered entrepreneurs (Wee (1981), p.6). Bank managers consulted their clients on business strategies, and sometimes acted as their financial managers. ${ }^{11}$ Cameron (1961, p.90-1) describes how the Société Générale actively encouraged mining companies and foundries to incorporate, obtained Royal charters for them, and provided the necessary financing. Banks thus carried out an intense coordination of industrial activities.

\subsection{Germany}

Germany is often cited as the quintessential case of bank-driven development. Between 1850 and 1870 the German economy experienced a quick industrialization which allowed it to become the first economic power on the continent. In this period its GNP grew at a yearly $2.4 \%$, well above the $1.9 \%$ European average and its own $1.6 \%$ growth rate of the previous two decades. ${ }^{12}$ Between 1860 and 1880 its industrial capacity grew at a yearly $4.6 \%$, up from $1.7 \%$ in the previous thirty years, and was concentrated in textiles and heavy industries (Bairoch (1982), p.292). Production of coal increased fivefold, and pig

\footnotetext{
${ }^{7}$ In the 1840 s it controlled mining companies responsible for more than a quarter of the whole coal extraction, Neuville [1974], p.123.

${ }^{8}$ See Société Générale (1922) for a detailed description of the bank's policy of sectoral investment.

${ }^{9}$ The Société Générale created one subsidiary and three investment trusts. The Banque de Belgique created two subsidiaries and two investment trusts, Morrison (1967), p.64-5. Chlepner (1930), p.10-2 and p.36-7, describes their role.

${ }^{10}$ The banks themselves did retain shareholdings of some corporations, see Lévy-Leboyer (1964), p.641 for the Banque de Belgique, and Société Générale (1922), annex 6, for the Société Générale.

${ }^{11}$ Cfr Chlepner ( 1926), p.86-7, and Wee (1981), p.5-6.

${ }^{12}$ Bairoch (1976a), p.281. In per capita terms the growth of GNP was $1.6 \%$ in Germany and $0.9 \%$ in Europe, p.286.
} 
iron sixfold, spurred a threefold expansion of railways (Mitchell (1980), tables E2,E8,G1). The German industrial credit banks, Kreditbanken, played an active role in industrial development combining commercial and investment banking activities and nurturing close relations with industry (Da Rin (1996)). Of the 40 Kreditbanken founded between 1848 and 1870, four accounted for most of the industrial credit activities: The Schaaffhausen Bankverein, the Disconto Gesellschaft, the Bank für Handel und Industrie and the Berliner Handelsgesellschaft. Their capitalization accounted for nearly half of that of all industrial credit banks, and they were also much larger than the unincorporated industrial credit banks (Privatbanken), which operated locally. The average founding capital of these four Kreditbanken was 33 million Marks (Riesser (1911), Appendix 3), versus only 1 million for the average Rhenish Privatbankier. ${ }^{13}$ These four banks used mainly their own capital as a source of finance, remaining well above $40 \%$ until 1870 (Tilly (1966a), ch.5 and 8). In Prussia, by far the largest German state, incorporations were granted discretionally by the government, and entry as a Kreditbank was restricted. Indeed the government granted a joint-stock charter only to the Schaaffhausen Bankverein (Tilly (1966a), p.111). The other three Kreditbanken were organized as unincorporated limited liability companies. This constraint seems to have been binding, for when incorporation was liberalized in 1871, there were scores of new joint-stock banks. The financial sector remained fairly concentrated even afterwards, as a small number of very large Kreditbanken, the Grossbanken, dominated the smaller Provinzbanken (Jeidels (1905), p.112). Grossbanken acquired several local and regional Provinzbanken in order to retain a leading position and keep up with the growth of the economy. Six large bank groups, Konzernen thus came to dominate the industrial credit sector, which independent Provinzbanken were never able to challenge (Riesser (1911), part IV).

The credit channeled by Kreditbanken increased at an average yearly rate of $19.4 \%$ between 1852 and 1870, from 20 to 492 million Marks (Hoffman (1965), p.743). Between 1851 and 1870, 259 firms incorporated, up from 102 in the previous 25 years. Incorporation was typically managed with the help of an industrial credit bank. ${ }^{14}$ Kreditbanken acted as universal banks, providing loans and issuance of securities for their clients but also retaining equity positions in those firms (Riesser (1911), p.62-6). Their activity concentrated in few regions and industries: The Rhineland, Ruhr, Silesia and Saxony; in mining, machinery, textiles, construction, and railways.

German banks frequently took equity participations in their clients. Riesser (1911,

\footnotetext{
${ }^{13}$ Tilly (1966a), p.66. Rhenish Privatbankiers were the earliest and largest to engage in industrial finance in Germany.

${ }^{14}$ Riesser (1911), p.38. Kreditbanken also supported firms that assumed unincorporated limited liability form (Kommanditgesellschaft auf Aktien). See also Jeidels (1905) and Motschmann (1915) for detailed accounts of the role of Kreditbanken in industrial finance.
} 
p.339-40) describes in detail the participations taken by Kreditbanken in railways and heavy industries in the 1850s. These equity holdings absorbed much of the banks' capital: from the $13 \%$ of the Schaaffhausen Bankverein (p.72) to the $50 \%$ of the Bank für Handel und Industrie (p.81). Many equity holdings arose from illiquid loans during the 1857 economic slump, but with time several of them became profitable.

Universal banking was overall profitable, though losses were experienced in the early years (Tilly (1966a), ch.8). The average dividend in the 1850 s and 1860 s was $6.7 \%$ for the Bank für Handel und Industrie, 7.0\% for the Disconto Gesellschaft, $7.2 \%$ for the Schaaffhausen Bankverein, and 7.3\% For the Berliner Handelsgesellschaft (Riesser (1991), p.68). Moreover each bank accumulated several million Marks of surplus reserves.

The personal nature of their business relationships allowed them to elicit and circulate information effectively, and to have a strong influence on investment decisions (Da Rin (1996), p.29-30). As Richard Tilly (1966b, p.181) argued: "the contribution of German bankers to the mobilization of capital operated not only on the supply side but on the demand side as well; by organizing and allying themselves so closely with industrial enterprises, bankers strengthened and in part represented the demand for investment funds."

In Germany industrial concentration increased since the recession of the 1870s. Concentration took the form of both cartelization, which was both legal and politically popular, as well as mergers and acquisitions. Riesser (1911) devotes a large section of his book to this issue. He notices that Kreditbanken were more active in fostering concentration in industries which depended heavily on external finance. For example, in electrical equipment about forty joint-stock companies were created in the 1880s and early 1890s, mostly financed by banks. By 1900, however, only 28 had remained, organized in seven industrial groups. This consolidation process had been orchestrated by the major Kreditbanken, each of which backed one industrial group. Similarly, in the extractive industries banks exerted influence by either actively spurring concentration or simply upholding it. Banks had been the main financiers of the coal and iron works in the Ruhr in the 1860s, and during the 1880s they helped groups like Krupp, Hoesch and the Rhenish Steel Works to become the dominant market players. Feldenkirchen (1991, p.127) provides additional evidence on the role of bank in the concentration of heavy industries, and remarks that when cartels proved brittle in the recession of the 1880s, banks promoted concentration through acquisitions. Finally, some of the most interesting examples come from the chemical industry (see Da Rin (1998)). In the 1860s and 1870s, the large universal banks were instrumental in the creation of this highly innovative industry, financing firms like BASF, AGFA, Degussa, Hoechst and Bayer. While these firms were extremely successful, banks refrained from financing further entrants after this initial founding wave. This enabled these pioneer-turned-incumbent firms to dominate the various segments of the chemical industry (see also Beer (1959), ch.11). 


\section{$2.3 \quad$ Italy}

The last case we consider is Italy, which industrialized rapidly between the early 1890s and World War I. Between 1893 and 1913, its industrial output grew at a yearly 4.8\%, up from $0.5 \%$ in the previous two decades, and GDP grew at $2.5 \%$, up from $0.6 \%{ }^{15}$ The yearly growth rate of manufacturing production (1896-1913) ranged from 4.0 to $6.2 \%$ according to different estimates. ${ }^{16}$ Between 1894 and 1913 the yearly growth rates were $15 \%$ in electricity, $12.9 \%$ in chemicals, $10.7 \%$ in iron and steel, $7.5 \%$ in engineering, all higher than in other European countries (Cohen (1967), p.364). The share of producers' goods in total production rose from $28 \%$ to $47 \%$ (Romeo (1972), p.68). Private industrial credit banks ('banche di credito ordinario') played a key role in channeling savings towards industrial high growth sectors and in influencing the direction and timing of investments. The Banca Commerciale was founded in 1894 and the Credito Italiano in 1895, just before the economy made its 'big leap.' They controlled nearly two thirds of the assets of all industrial credit banks, which increased at a yearly rate of $4.9 \%$ over the two decades up to world war I. ${ }^{17}$ Their funding came more from their own capital rather than from deposits, which typically accounted for less than a quarter of liabilities (Confalonieri (1976 and 1982), statistical annexes). The few competitors to the Banca Commerciale and the Credito Italiano were smaller banks, which generally operated in Northern Italy (Confalonieri (1976, vol.3). The two leaders spurred investment in electricity, mechanical engineering, metals, and automobiles, while overlooking traditional industries like textiles. ${ }^{18}$ Also, they focused their efforts toward firms in the Northern 'triangle' between Genova, Torino and Milano (Aleotti (1990), p.58-60).

In the case of Italy sheer size seems to have been enough to deter entry by other large industrial credit banks. Indeed the Banca Commerciale and the Credito Italiano were successful in imposing exclusive relationships to most of their clients (Confalonieri (1976, vol.2), p.329).

Italian industrial credit banks were another instance of universal banking. They encouraged firms to incorporate and managed the issue of their equities and bonds on the stock market. Between 1900 and 1913 Italian joint stock companies grew from 848 to 3,069, and between 1900 and 1907 they raised about 2.7 billion lire, mostly on the stock exchange (Ale-

\footnotetext{
${ }^{15}$ Fuà (1965), tab.1 and 3. Similar data are in Gerschenkron (1962), p.75. The yearly per capita growth of GNP between 1890 and 1913 was 1.5\%, slightly higher than the European average of 1.4\%, Bairoch (1976a), p. 286.

${ }^{16}$ Federico and Toniolo (1988), discuss the reliability of different estimates.

${ }^{17}$ Cohen, (1972), p.78. Confalonieri (1976), vol.3, provides a thorough discussion of the evolution of the Italian financial system.

${ }^{18}$ As we can read in the early reports of the Banca Commerciale, the bank strove to be 'active part ... in all the major and worthy signs of the economic development in our country' (Confalonieri (1976), vol.3, p. 42 , our translation).
} 
otti (1990), p.61-7). In 1897 there were 30 listed companies in the Milano Stock Exchange, which grew to 169 by $1908 .{ }^{19}$ Both the Banca Commerciale and the Credito Italiano played a major role in planning and financing these operations. Between 1894 and 1906 the Banca Commerciale took part in 145 capital market operations, and the Credito Italiano in $84 .{ }^{20}$ Confalonieri (1976, vol.3) describes in detail the involvement of the Banca Commerciale in the steel, electric and mechanical sectors, and of the Credito Italiano in sugar refining, iron, and chemicals (1976, vol.2). He concludes that investment banking activities favored their role as promoters of industrial undertakings.

Investments in industrial securities (both equity and bonds) by the Banca Commerciale and the Credito Italiano ranged from 5\% to 10\% of their assets between 1895 and 1906, and contributed a corresponding share of their net income. ${ }^{21}$ Large loans to large industrial firms accounted for another 20-30\% of assets and income (Confalonieri (1976), vol.3, p.486). The net income of Banca Commerciale Italiana rose from 1.3 million lira in 1895 to 12.7 millions in 1913, and that of Credito Italiano from 0.9 to 5.4, respectively (Confalonieri (1976 and 1982), statistical annexes). In both cases income growth was steady and accelerating.

Like the Belgian banks with investment trusts, the Italian banks managed their industrial participations through subsidiaries. But unlike their Belgian colleagues, they did so by acquiring control in industrial companies which they used as holding companies. This was often the case with fast growing industries: electricity, chemicals, iron and steel. ${ }^{22}$ Gerschenkron (1962, p.88) argued that in Italy "[a]s in Germany, not only capital, but a good deal of entrepreneurial guidance was channeled to the nascent and expanding industrial enterprises. As in Germany, the policy was to maintain an intimate connection with an industrial enterprise and to nurse it for a long time before introducing it to the capital market."

Italian industrial credit banks were also protective of the competitive positions of their clients. For example, Cohen (1967, p.375), writes that 'banks recognized that their profits were related to the expansion of the industries in which they were involved. Competition was inimical to the banks' best interests; expansion was not, so the banks encouraged it.'

\footnotetext{
${ }^{19}$ Most of these were in electricity, transportation, and textiles, Aleotti (1990), p.62.

${ }^{20}$ These operations were flotations, mergers and acquisitions, capital increases, debt conversions, see Confalonieri (1976), vol.2, p.341-5.

${ }^{21}$ Confalonieri (1976), vol.2, p.322, and vol.3, p.476. The Banca Commerciale had larger participations but also a larger balance sheet than the Credito Italiano. Both banks invested substantial amounts in public bonds and in short term loans.

${ }^{22}$ Some such cases were: Società Edison (BCI), Vizzola (BCI), Società Industrie Elettro-Chimiche (CI), Unione Italiana Concimi (CI), Montecatini (CI), Ferriere Italiane (CI), Società Elba, Acciaierie Terni (BCI), and Acciaierie Savona (BCI). Confalonieri (1976), vol.3, chapter 3, details their history, which is also studied by Cohen (1967), p.378-80, and Romeo (1972), p.77-83. Holding companies were used to coordinate bank activities also in the mechanical industry, but to a lesser extent. Such instances were offered by Officine Meccaniche (BCI and CI) and Cantieri Pattison (CI). BCI also used the Società Generale di Navigazione Marittima to coordinate its activity in steamship, see Confalonieri (1976), vol.2, chapter 6.4.
} 
His discussion of the steel industry is instructive. The industry was dominated by the three firms of the Terni-Savona group, which had been financed by Banca Commerciale and Credito Italiano. In 1904 the law for the development of Naples granted a ten year tax exemption to new enterprises located there. This created a unique growth opportunity for the only mid-sized independent firm, the Piombino of the Bondi family. However, such an investment by Piombino in Naples would have threatened the dominance of the TerniSavona group. In 1905 the two banks set up a new firm, Ilva, whose steel mills were located near Naples. Ilva eventually took the leadership of the bank-supported cartel (see Cohen (1967, p.379-80) and Confalonieri (1976), vol. III, ch.3). The move was successful, since by 1911 the cartel produced virtually all the Italian pig iron and $58 \%$ of the steel market (Cohen (1967, p.380). In his monumental work, Confalonieri $(1976,1982)$ provides further examples of bank support for industry consolidation. He emphasizes the role of the Banca Commerciale and Credito Italiano after 1907, when overcapacity in some industries brought several firms into distress. The two banks fostered concentration in the heavy industries, in high-tech industries like fertilizers, and even in more traditional industries like textiles.

The historic evidence we have presented raises a number of important questions. What does it mean for a bank to promote industrialization and to be a catalyst? Under what circumstances can private banks take such a role, and under which conditions would they actually choose to take it? What are the costs and benefits of such actions? Also, is the historical similarity in financial market structures across countries a mere coincidence, or is there a definite relationship between bank size, bank market power and bank activity in industrial promotion? What is the significance of universal banking for the promotion of industrialization in emerging economies? And what is the relationship between concentration in banking and concentration in the industrial sector?

To answer these important questions and to make sense of these episodes in economic history, we seek guidance from theory. Theories of the big push have so far focussed on identifying the reasons for the multiplicity of equilibria and for the existence of coordination failures, but have given little attention to addressing possible remedies. In particular, the role of financial intermediaries has not been addressed in this literature. This is our starting point for developing a model to examine under what circumstances profit-motivated banks would act as catalysts for industrialization. 


\section{A simple model of coordination failures}

\subsection{The model set-up}

Our model lasts two periods. There are $Q$ entrepreneurs, who have a choice of either doing nothing, or starting a firm. ${ }^{23}$ For simplicity, we assume that the $Q$ firms are identical and indexed by $q=1 \ldots Q$. Without loss of generality we will speak interchangeably of firms and entrepreneurs. Creating a firm entails an investment of $F$ in the first period, which generates profits in the second period. To focus on the coordination problem, we simplify the analysis by assuming that there is no uncertainty about the future outcome of the investment, nor any asymmetric information. We will relax these assumptions later. Each entrepreneur has an endowment of $W$, with $W<F$, and thus needs to raise an external amount of finance, equal to $X=F-W>0$. Let $K$ be the number of entrepreneurs investing. The (gross) return to any particular firm $q$ is given by $f(K)$. This is assumed to be an increasing function of $K$, so that an individual entrepreneur's return depends positively on the investment decisions of all other entrepreneurs.

Entrepreneurs raise funds from financial intermediaries. We will focus on banks as financial intermediaries. Accordingly, we first examine pure debt contracts. Let $\sigma$ be the (gross) return to the investor (i.e. the bank). We denote the lending rate by $i$, so that $\sigma=(1+i) X$. Later, we will extend the model to allow for more general securities, where investors choose the functional form of $\sigma .^{24}$

For simplicity, we assume that all investors face a constant cost of capital. Let $r$ denote the riskless rate of return, and let $\beta=\frac{1}{1+r}$ be the discount rate. We assume that:

$$
\beta f(1)<F, \quad \beta f(Q)>F
$$

This ensures the existence of multiple equilibria, which is the focus of our analysis. The net present value of firm's $q$ profits when $K$ firms are set up (including $q$ ) is then given by:

$$
\pi(K, i)=\beta[f(K)-\sigma]=\beta\left[f(K)-\left(1+i_{q}\right) X\right]
$$

where $i_{q}$ is the interest rate paid by firm $q$. The investor's net profits for investing in entrepreneur $q$ are then given by:

\footnotetext{
${ }^{23}$ Alternatively, we can think of this as a choice between investing in traditional versus new technologies. See Murphy, Shleifer and Vishny (1989).

${ }^{24}$ Throughout the analysis, however, we assume that a contract with an entrepreneur can only be conditioned on the returns of her own firm, but not on the returns of other entrepreneur. This is necessary to eliminate some artificial solutions where the coordination problem in the economy can be trivially solved through sophisticated contracting. See Segal (1999) for a similar restriction on bilateral contracting.
} 


$$
\rho_{q}\left(i_{q}\right)=\beta \sigma_{q}-X=\beta\left(1+i_{q}\right) X-X
$$

The interest rate offered to entrepreneur $q$ depends on the financial market structure. We use a simple price-leadership model that allows for a one-dimensional parameterization of the intensity of competition in the financial market. In particular, we assume that there exists a competitive fringe of $z$ 'small' investors which can finance exactly one entrepreneur each. Moreover, there exists a lead investor ( $L$ henceforth), who can always finance $(Q-$ $z$ ) entrepreneurs. The financial market is perfectly competitive when $z=Q$, so that $L$ disappears and the lending rate $i$ equals the deposit rate $r$. If the fringe is smaller $(0<z<Q)$, $L$ has some market power. If the fringe disappears $(z=0), L$ is a monopolist.

The sequence of actions is as follows. $L$ moves first and offers contracts to entrepreneurs. The fringe investors observe $L$ 's offers, and then make their own offers to entrepreneurs. Finally entrepreneurs simultaneously decide whether or not to set up a firm and which offers to accept.

\subsection{Multiple competitive equilibria and the need for coordination}

In this section we examine the rational expectations equilibria when financial markets are competitive. In this case $z=Q$, and there is no lead investor but only a competitive fringe. We immediately state:

Proposition 1 With a competitive financial market there exist two Pareto-rankable competitive equilibria, one where all entrepreneurs invest, and one where no entrepreneur invests.

Proposition 1 follows immediately from $i=r$ for all $q$, and the assumption that $\beta f(1)<F$ and $\beta f(Q)>F$. The intuition is that whenever there is a 'large' number of entrepreneurs (here $Q$ ) starting new firms, then complementarities make it worthwhile for all entrepreneurs to also invest. Likewise, when only 'few' entrepreneurs (here none) set up a firm, it is not profitable for others to also do so. We name the equilibrium with no entrepreneurs the $S Q E$ ('Status Quo' Equilibrium) and the equilibrium with all entrepreneurs investing the EME ('Emerging Market' Equilibrium).

The existence of multiple equilibria is a coordination failure. In the $S Q E$ the belief that no entrepreneur will set up a firm is self-fulfilling, i.e., it implies that no entrepreneur actually undertakes that costly action. Likewise, in the $E M E$ the belief that many entrepreneurs are setting up a firm justifies the investments by many entrepreneurs.

Previous work in this literature has focussed on the possible existence of a coordination failure and characterized the conditions under which either equilibrium may attain. The 
focus of our paper is instead on how to eliminate the $S Q E$. To break the beliefs that sustain the $S Q E$ requires that agents know that the $S Q E$ cannot be an equilibrium any longer. We therefore say that coordination has been achieved if and only if the $S Q E$ is no longer an equilibrium. In explaining emerging markets, we thus do not rely on a spontaneous coordination of beliefs. This would assume rather than derive it. Instead, we ask under what circumstances financial intermediaries such as banks can promote the emergence of markets in a way that does not rely on spontaneous or fortuitous coordination.

One may obviously ask why the focus on banks? We have already presented historic evidence on the importance of banks. There are also some interesting theoretical reasons. ${ }^{25}$ An interesting implication of proposition 1 is that an economy, where there are only small savers and direct financing from savers to firms, is not able to achieve coordination and induce the emergence of new markets. This suggests that some type of financial intermediation is necessary to achieve coordination. ${ }^{26}$ Financial intermediaries, such as banks, are a natural potential candidate for coordination. First, the availability and terms of external financing directly influence entrepreneurs' decisions to set up a firm. Second, financial intermediaries provide funds, which are an essential input for most firm. Moreover, financial intermediaries interact with many entrepreneurs and thus have a unique opportunity to induce coordination. Finally, they have a financial self-interest in the emergence of new markets.

\subsection{Banks as catalysts}

We now examine how the lead investor $L$ can induce coordination. To this purpose we introduce the notion of a 'catalyst,' i.e., an agent whose actions precipitate a change. The question we ask is under what circumstances an investor may act as a catalyst for emerging economies.

In order to achieve coordination it is necessary for all entrepreneurs to believe that a 'critical mass' of entrepreneurs will start a new firm. The critical mass $M$ is defined as the smallest number of entrepreneurs which, by creating new firms, make starting a firm the only equilibrium strategy for all other entrepreneurs. Formally, $M \in(1, Q)$ is a critical mass if $\pi(M, r)<W$ and $\pi(M+1, r) \geq W$.

It is useful to break down the profits of $L$ into two parts: those profits which result from mobilizing the critical mass, and those made on all other entrepreneurs. Let $i_{q}$ and $i_{z}$ be

\footnotetext{
${ }^{25}$ While we emphasize the role of financial intermediaries, we do not claim that they are the only possible coordination mechanism. Indeed in Section 4.3 we discuss alternative institutions that may also induce coordination.

${ }^{26}$ Note that this argument complements the argument by Diamond (1984) that financial intermediaries are needed for organizing the monitoring process that individual savers could not undertake on their own.
} 
the interest rates paid by firms in the critical mass and by firms outside the critical mass, respectively. We then write $L$ 's profits as:

$$
\rho^{L}=\psi+\nu
$$

where

$$
\psi=\sum_{q=1}^{M} \rho_{q}^{L}\left(i_{q}\right)=\sum_{q=1}^{M} \beta\left(1+i_{q}\right) X-X
$$

are the net profits made on the entrepreneurs within the critical mass, and:

$$
\nu=\sum_{q=Q-z-M}^{Q} \rho_{q}\left(i_{z}\right)=\sum_{q=Q-z-M}^{Q} \beta\left(1+i_{z}\right) X-X
$$

are the net profits made on the entrepreneurs outside the critical mass.

Proposition 2 Suppose $L$ uses pure debt contracts. Then:

(i) Inducing coordination is costly: $\psi<0$;

(ii) There exists a critical value $\widehat{z}$ such that $L$ induces coordination if and only if the competitive fringe has size $z<\widehat{z}$;

(iii) The average cost of capital to entrepreneurs is higher than the riskless interest rate $r$.

The proof is in the Appendix. We illustrate the intuition behind Proposition 2 with the help of Figure 1, where for simplicity we draw $\pi(q, r)$ as a continuous function. $L$ needs to convince $M$ entrepreneurs to set up a firm despite their pessimistic beliefs. It can do so by offering them loans in which the interest rate is low enough to make them willing to set up a firm. $L$ makes a loss on each of the loans in $M$. Area $\psi$ in Figure 1 indicates $L$ 's losses. Notice that $L$ cannot raise the interest rate on these loans, otherwise firms in the critical mass $M$ would not invest. Once firms in the critical mass have been offered loans which convince them to create a firm, all other entrepreneurs are also willing to follow suit. Thus $L$ sets the interest rate for entrepreneurs outside the critical mass at the level $i_{z}$, so as to maximize its profits $\rho^{L}$. Area $\nu$ in Figure 1 indicates $L$ 's profits from these loans. It is clear that the larger the competitive fringe the fewer entrepreneurs $L$ can finance outside the critical mass. This puts an upper bound to $\widehat{z}$, since $L$ needs some profits from entrepreneurs outside the critical mass, to recoup the losses from investing in the critical mass.

An interesting insight of Proposition 2 is that while the presence of $L$ allows the economy to move to the EME, entrepreneurs face a higher average cost of capital than under spontaneous coordination with perfectly competitive financial markets. This shows that the existence of market power, while helpful to promote coordination, also has a cost. 
The main point of our model is that, in order to act as a catalyst, an investor needs to be large enough to mobilize a critical mass of entrepreneurs, as well as possess enough market power to make profits on the other entrepreneurs who start new firms, so as to recoup the cost of coordination. To express our results in the simplest possible fashion, we have chosen to model the financial market with a Stackelberg model where a lead investor is a first mover and a fringe of perfectly competitive investors are followers. The important part of this assumption is that $L$ is a first mover, and that it has enough market power to recoup the cost of coordination. By financing a critical mass, $L$ acts as a catalysts for the investment of all other entrepreneurs. The way we model the fringe is not as important. All that matters is that second mover investors do not compete away all the rents that $L$ needs to recover the cost of coordination. Undifferentiated Bertrand competition between $L$ and one or several other investors would destroy any rents accruing to $L$. But other models of imperfect competition, such as Cournot, differentiated Bertrand, or others would also leave some rents for $L$. The general insight is thus that the structure of the financial market affect the bank's ability to engage in coordination.

\subsection{The role of equity finance}

So far we restricted investors to only provide standard debt contracts. In this section we show that the cost of coordination can be reduced, and sometimes even eliminated, if $L$ is allowed to offer equity contracts. Suppose that $L$ holds some equity and denote its holding by $\alpha$.

Proposition 3 If $L$ can offer entrepreneurs equity finance then:

(i) $\psi$ is a decreasing function of $\alpha$;

(ii) $\widehat{z}$ is an increasing function of $\alpha$;

(iii) $\rho^{L}$ is an increasing function of $\alpha$;

(iv) Under pure equity finance there exists $\widehat{F}$ such that $\psi \leq 0$ iff $F>\widehat{F}$;

(v) Under pure equity finance there exists $\widehat{W}$ such that $\psi \leq 0$ iff $W>\widehat{W}$.

The proof is in the Appendix. The main intuition for Proposition 3 is that when $L$ finances entrepreneurs with equity, it participates in the profits obtained in the EME. In other words, $L$ partially internalizes the externality that is at the root of the coordination problem. This reduces the cost of subsidizing entrepreneurs in the critical mass and makes coordination easier. The decrease in the coordination cost also means that the competitive fringe can be larger. Part (iv) says that coordination costs will (will not) disappear when the costs of creating a firm are sufficiently large (small). For a given $W$, a higher investment cost increases $L$ 's stake, which reduces the cost of mobilizing a critical mass. Part $(v)$ says that coordination costs will (will not) disappear when the entrepreneur's endowment 
is sufficiently small (large). Again, for a given $F$, a lower endowment $W$ increases $L$ 's stake and thus his ability to capture the rents from coordination.

\subsection{Optimal securities and incentives}

So far, we have examined a model that uses the standard securities used by banks, namely debt and equity. In this section we turn to the issue of optimal securities. There exists a vast literature on security design, where different contractual or informational imperfections lead to different optimal securities. ${ }^{27}$ A potential problem with introducing optimal securities is that they can be very sensitive to specific model assumptions. In this section we show that the optimal contract in the base model yields a result that is neither realistic nor robust. We also show that all the insights from the previous section continue to hold if we extend the model by incorporating incentive issues.

Consider the model as it stands. We have seen that the returns to $L$ are larger if it uses equity instead of debt. This is because with equity $L$ participates in the upside it creates by inducing coordination. If we look for $L$ 's optimal choice of security, it is immediate that the optimal contract would make the investor the full residual claimant. This can be achieved with some kind of reverse-debt contract - where the entrepreneur holds the fixed claim - or simply a buy-out contract, where the investor acquires the company and the entrepreneur receives a fixed payment. It is straightforward to show that with such a contract, there are never any costs of coordination. This result, however, is not very robust. In particular, it disappears once we allow for incentive concerns. More specifically, if $L$ is the full residual claimant, the entrepreneur is left with no incentive to provide effort for the venture. If the model focuses on only one problem, namely coordination, then the optimal contract takes the degenerate form of making the investor the residual claimant. But if we recognize that an optimal contract needs to solve several problems, such as a coordination problem and an incentive problem, then it needs to trade-off the benefits of allocating residual returns between the entrepreneur and the investor. ${ }^{28}$

In the Appendix we examine an extension of the model where there are both coordination and incentive problems. The main insight we gain from this exercise is that the results from the previous sections continue to hold. More precisely, if $L$ is made the residual claimant, then it could extract all the rents it creates from inducing coordination. But this leaves entrepreneurs with no incentives to exert optimal effort. Since we cannot make both the entrepreneur and the investor the residual claimant, the optimal contract needs to trade off the benefits from providing entrepreneurial incentives with the benefits from allowing $L$

\footnotetext{
${ }^{27}$ See, for example, Gale and Hellwig (1985) or Hart and Moore (1995), and Harris and Raviv (1991) for a useful survey.

${ }^{28}$ Another reason why the entrepreneur has to bear some residual risk might be adverse selection.
} 
to recoup the cost of coordination. The optimal contract, therefore, does not allow $L$ to capture all of the rents it creates through coordination. This generates the need for market power, and we get back all of our previous results.

\subsection{Heterogeneous firms}

The main model uses $Q$ identical firms. In this section we outline how the model can be extended to the case of heterogeneous firms without losing its fundamental insights. Since the formal analysis is lengthy and complex, we relegate it to the Appendix. Here we motivate the choice to develop such a complex model and highlight the additional insights we gain from such an exercise. Developing a model with heterogeneous firms is interesting in a number of respects. Firms may clearly differ in terms of their own profitability. Maybe even more important, they may differ in terms of the externality that they provide for other firms. Interestingly, this opens up the possibility for $L$ to choose the critical mass strategically.

We examine a very general model where the returns for entrepreneur $q$ are given by $f(K, q)$, where $K$ is the vector of all the other entrepreneurs starting a new firm. The only assumption we will make is that $f(K, q)$ is a super-modular function of $K$. This says that all the externalities are non-negative. This is a very sparing assumption, since it allows each $q$ to have its distinct externality on all other firms in $K$.

An important difference to the base model is that with heterogeneous firms, there may be more than two competitive equilibria. However, we show that there always exists a 'maximal' and a 'minimal' equilibrium. If an entrepreneur sets up a new firm in any equilibrium, then she also does so in the maximal equilibrium. The maximal equilibrium is thus the most inclusive, and it Pareto-dominates all other equilibria. It is natural to call this equilibrium the $E M E$. It should be noted, however, that the $E M E$ is in general not socially efficient, since it may still exclude some firms that are not profitable on their own, but that would provide a positive externality for all others. There exists also a minimal equilibrium that has only those entrepreneurs (possibly none) starting a firm that also do so in all higher equilibria. This equilibrium is Pareto-dominated by all others, and we naturally call it the $S Q E$.

An interesting aspect of the model with heterogeneous firms is that the equilibria induced by $L$ will in general look different than the competitive equilibria. This is because $L$ can internalize at least some of the externalities. We show that the highest equilibrium induced by $L$ always includes (weakly) more firms than the highest competitive equilibrium, although it still includes (weakly) fewer firms than the outcome that would maximize economy-wide output. A potential problem with achieving coordination with heterogeneous firms is that $L$ may not always want to implement the $E M E$. We show that the conditions on size and 
market power are necessary, but they may not always be sufficient to induce the EME. Nonetheless, they are sufficient to at least induce an equilibrium that is better than the $S Q E$.

Another important aspect of the model with heterogeneous firms is that $L$ chooses the critical mass strategically. For example, it may prefer to finance an entrepreneur whose firm is only mildly profitable, or even outright unprofitable, but that provides a large positive externality on other firms. ${ }^{29}$ Therefore, there may be more than one critical mass and more than one target equilibrium. Different combinations of firms may all work to induce an equilibrium that is at least as large as the $E M E$, and the resulting equilibrium may depend on what critical mass is mobilized. $L$ may include some entrepreneurs in the critical mass that would not have started a firm in the EME. Moreover, once some of these entrepreneurs outside of the EME start a firm as part of the critical mass, there may be yet some other entrepreneurs outside EME that now do so as well. Heterogeneity of firms thus allows for a bewildering variety of ways of mobilizing critical masses and reaching different outcomes. However, the basic logic of how to induce a higher equilibrium continues to apply. In particular, we show that with debt contracts $L$ always makes losses on all entrepreneurs in the critical mass. This implies that there is always a cost of coordination. And as a consequence $L$ needs to be not only large enough, but also requires sufficient market power to cover coordination costs. And we show again that the use of equity reduces and sometimes even eliminates the cost of coordination.

\subsection{Bank concentration and concentration in the industrial sector}

The model so far identifies the benefits of having a lead bank with sufficient size and market power to induce a critical mass of investments. In this section we extend the model to examine the potential disadvantages of such a mechanism. In our historical analysis, we noted that the concentration in banking was often associated with concentration in the industrial sector. The powerful banks thus discouraged competition among firms, especially in those industries where they had already financed the incumbents.

To examine these issues, we now provide a simple extension of our base model that allows us to examine the relationship between banking concentration and concentration in the industrial sector. ${ }^{30}$ In the first period, banks can finance a set of firm $Q$, that we can think of as pioneers in their own industries. In the second period, banks can refinance these incumbents. In addition, we introduce a set of potential entrants. For simplicity,

\footnotetext{
${ }^{29}$ Note that historically banks have often invested in infrastructural projects whose payoff takes a long time to arrive, if it does at all. Investment in railways and canals are typical examples of infrastructural projects with substantial externalities on the rest of the industry, even if unprofitable by themselves.

${ }^{30}$ For other models on the ills of market power in financial markets, see Hart (1983) or Aghion, Dewatripont and Rey (1997).
} 
we assume that for every incumbent, there is exactly one potential new entrant. Both types of firms require an investment of $F$ per period. Without entry the returns to the incumbent are given by $f_{2}^{m}$, where the superscript $m$ stands for monopoly. With entry, the returns to the incumbent and the entrant are given by $f_{2}^{d i}$ and $f_{2}^{d e}$, respectively, where the superscripts $d i$ and $d e$ stand for duopoly-incumbent and duopoly-entrant. ${ }^{31}$ We assume that $\left(\beta f_{2}^{m}-F\right)>\left(\beta f_{2}^{d i}-F\right)+\left(\beta f_{2}^{d e}-F\right)$. This is a standard assumption that ensures that a monopoly maximizes profits even though competition may be socially desirable.

Consider now the decision of a bank in the second period. If competition reduces firm profits, a bank never wants to finance an entrant to its incumbent. However, there may be profitable opportunities to finance entrants to incumbents financed by another bank. We call a potential entrant to a fringe-financed incumbent a "fringe-entrant" and a potential entrant to a lead-bank-financed incumbent a "lead-entrant." The lead bank will never finance a lead-entrant, but may well consider financing a fringe-entrant. A fringe bank, on the other hand, is willing to finance both lead-entrants and fringe-entrants, as along as it is not an entrant to its own incumbent.

As in the base model, the lead bank makes its investments first, and the fringe follows. We assume that $f_{2}^{d i} \geq f_{2}^{d e}$, so that all banks first refinance their own incumbents by lending them an amount $X$. We denote the number of fringe-entrants financed by the lead bank by $E_{L} \in[0, z]$, and the number of (fringe- or lead-) entrants financed by fringe bank by $E_{z}$. Also, we allow for a fairly general specification of $E_{z}$, imposing only that $E_{z}$ is an increasing function of the fringe bank's first period profits $\left(\frac{\partial E_{z}}{\partial i_{z}}>0\right)$, as well as the number of banks in the fringe $\left(\frac{\partial E_{z}}{\partial z}>0\right)$.

Let $p$ be the probability that a potential entrant is financed. There is a difference between $p_{z}$ and $p_{L}$, i.e., between the probability that a fringe-entrant is financed (and enters the market of a fringe-financed incumbent), and the probability that a lead-entrant is financed (and enters the market of a lead-bank-financed incumbent). If the lead bank invests in $E_{L}$ fringe-entrants, there are $Q-E_{L}$ potential entrants left (of which $Q-z$ are lead-entrants and $z-E_{L}$ are fringe-entrants). It follows that $p_{L}=\frac{E_{z}}{Q-E_{L}}$ and $p_{z}=\frac{E_{L}}{z}+\left(1-\frac{E_{L}}{z}\right) \frac{E_{z}}{Q-E_{L}}$, and that $p_{z}>p_{L}$ (with a strict inequality whenever $E_{L}>0$ ). This already shows that competition is always weaker in those industries that are financed by the lead bank.

We can now solve for the optimal choice of $E_{L}$. Using standard notation, $L$ maximizes $\rho_{2}^{L}=(Q-z)\left[\left(1-p_{L}\right) \pi_{2}^{m}+p_{L} \pi_{2}^{d i}\right]+E_{L} \pi_{2}^{d e}$. Increasing $E_{L}$ has two opposite effects. First, there is a (positive) direct effect, as $L$ makes profits from financing fringe-entrants. Second, there is a (negative) spillover effect, since an increase in $E_{L}$ increases $p_{L}$. If $L$ finances more fringe-entrants, then the fringe banks will have fewer fringe-entrants to finance, and will

\footnotetext{
${ }^{31}$ For simplicity, we assume that returns $f_{2}^{x}$, where $x=m, d e, d i$, are independent of $K$. It is straightforward to relax this assumption.
} 
therefore finance more lead-entrants.

Let $\theta \equiv \pi_{2}^{d e} /\left(\pi_{2}^{m}-\pi_{2}^{d i}\right)$ denote the ratio of the lead bank's benefit of financing a fringeentrant $\left(\pi_{2}^{d e}\right)$ to the potential cost of gaining (through the spillover effect) a competitor for one of its incumbent firms $\left(\pi_{2}^{m}-\pi_{2}^{d i}\right)$.

Lemma 1 Define $\underline{\theta}=\frac{(Q-z) E_{z}}{Q^{2}}$ and $\bar{\theta}=\frac{E_{-}}{(Q-z)}$. Then:

(i) For $\theta<\theta, L$ is 'defensive' and chooses $E_{L}=0$;

(ii) For $\underline{\theta}<\theta<\bar{\theta}, L$ is 'moderate' and chooses $E_{L} \in(0, z)$;

(iii) For $\theta>\bar{\theta}, L$ is 'aggressive' and chooses $E_{L}=z$.

The proof is in the Appendix. The intuition for this Lemma is that a higher benefit-tocost ratio $\theta$ increases $L$ 's interest in financing fringe-entrants. For low and high values we naturally find corner solutions, where $L$ finances either no or all fringe-entrants.

We are now in a position to examine the main question of this section: How does the financial market structure affect competition in the industrial sector. For this, we want to examine the effect of our measure of competition in the banking sector, $z$, on the total amount of competition in the industrial sector, as measured by $E=E_{z}+E_{L}$. We immediately state:

Proposition 4 An increase in the competition in the financial sector (z) has three different effects on the amount of competition in the industrial sector (E):

(i) An increase in $z$ increases the number of entrants financed by the fringe banks: $\frac{d E_{z}}{d z}>0$. This effect is relevant for all values of $\theta$.

(ii) An increase in $z$ increases the number of fringe-entrants $E_{L}$ that the lead bank can finance: $\frac{d E_{L}}{d z}>0$. This effect is relevant only when $\theta>\underline{\theta}$.

(iii) The increase in $E_{z}$ increases the potential spillover effect, reducing the lead bank's interest to finance fringe-entrants $E_{L}$. This effect is relevant only when $\theta<\theta<\bar{\theta}$.

The proof is in the Appendix. Proposition 4 identifies three potential channels for how changes in the banking market structure affect competition in the industrial sector. Consider first the case of a 'defensive' lead bank that never finances entrants $(\theta<\theta)$. Entrants can then be financed only by fringe banks. The larger the fringe, the more entrants will be financed. More competition in banking (as measured by the size of the fringe, $z$ ) thus increases competition in the industrial sector. Consider next the case of an 'aggressive' lead bank that is eager to finance fringe-entrants $(\theta>\bar{\theta})$. There is now a second effect: the larger the fringe, the larger is the set of fringe-entrants that the lead bank can finance. This second effect reinforces the first one. There is thus an even stronger link between banking competition and competition in the industrial sector. Consider finally the case of a 'moderate' bank $(\underline{\theta}<\theta<\bar{\theta})$. In addition to the two previous effects, a moderate lead bank 
also considers the spillover effect, which reduces the bank's interest in financing entrants. This third effect, however, is likely to be fairly small. Indeed, in the Appendix we derive conditions that ensures that the spillover effect is dominated by the first two effects.

So far we derived the optimal investment policies for the second period. The analysis for the first period is analogous to the base model, and we omit the details. However, there is one additional insight that is worth mentioning, namely that lead bank may have an incentive to retard financial development. To see why, consider $L$ 's maximization problem. $L$ wants to maximize $\rho^{L}=\rho_{1}^{L}+\beta \rho_{2}^{L}$, where the first period profits are given by $\rho_{1}^{L}=\psi+(Q-M-z)\left(1+i_{z}\right) X$ and, as before, $\psi$ is the loss on the critical mass. Note that the first period interest rate affects the first period profits of the fringe banks, which, in turn, affect their ability to finance entrants in the second period. The growth of the financial sector, measured in terms of the profits of the fringe banks, may therefore not please the lead bank. In fact, a higher $i_{z}$ increases the profits of the lead bank in the first period, but it also increases the profits of the fringe banks, that may now be used to finance entrants in the second period. Using the envelope theorem, the optimal choice of $i_{z}$ is given by the first order condition:

$$
(Q-M-z) X-\beta(Q-z) \frac{\pi_{2}^{m}-\pi_{2}^{d i}}{Q-E_{L}} \frac{d E_{z}}{d i_{z}}=0
$$

The first term identifies the direct gains from higher first-period profits. The second term identifies the indirect costs for the lead bank due to financial sector growth. Even if financial sector growth is good for the economy at large, the lead bank dislikes the additional competition from the fringe banks. As a consequence, the lead bank has an incentive to somewhat retard the development of the financial sector.

While the previous sections focused on the potential advantages of having large and powerful banks, here we identify a significant disadvantage, namely that large and powerful banks have a vested interest in preserving industrial monopolies. The analysis of this section shows that banking competition and industrial competition are likely to go hand in hand. This finding conforms with our historical analysis that emphasizes the lack of industrial competition in the countries with large and powerful banks. ${ }^{32}$

\section{The limits of the Gerschenkron-Schumpeter view}

The fundamental insight from our model is that for banks to play a role as a catalyst, they need to be sufficiently large and to have sufficient market power in order to be willing to

\footnotetext{
${ }^{32}$ The link between the financial system and industrial concentration has also been documented by Haber (1991), but with a different perspective. He looks at the cases of Brazil and Mexico, where underdeveloped capital markets induced industrial concentration not through banking concentration but by forcing firms to rely on family wealth and connections for their financing needs.
} 
incur the cost of coordination. The power of the theory is thus to identify the conditions under which we can or cannot expect banks to take the role of catalyst for industrialization. Our theory is consistent with the evidence from Section 2, which focussed on the success stories of Belgium, Germany and Italy, where a few large universal banks played a significant role in promoting industrialization.

In this section we take the theory one step further by confronting it with additional historic evidence. If our theory is useful in identifying the conditions under which their argument holds, we now want to concern ourselves with the limits of that argument. We structure this analysis in four parts. First, we consider historic evidence from some countries that failed to industrialize. Second, we discuss the political economy dimension of having large and powerful banks. Third, we look at the experience of countries that developed relying on mechanisms other than coordination by private banks. Fourth, we discuss what formal empirical evidence exists in the literature, and what additional predictions can be gained from our model.

\subsection{Violating the necessary conditions: evidence from countries that failed to industrialize}

Our theory establishes the necessary conditions for a bank to be able to act as a catalyst for industrialization. We now look at what happens when these conditions are violated, and examine the experience of some countries that failed to industrialize: Russia, Spain, and pre-1890 Italy. The failure to industrialize can clearly be attributed to multiple causes. This evidence therefore cannot provide a definite test of our theory. What we want to emphasize, however, is that the necessary conditions for bank coordination were not satisfied in each of these countries.

Crisp (1967) shows that Russian industrial credit banks developed slowly and remained small and dispersed over an immense country. The behavior of the Russian state was far from enticing a catalytic role of banks. The state maintained a tight grip on new economic activities, and kept limiting the growth of banks. For example, the government viewed as usury any activity involving a monetary compensation for risk-taking. This attitude strongly limited how much banks could charge their borrowers, and therefore their market power. ${ }^{33}$ Only from the 1890s did banks based in St. Petersburg start engaging in some industrial credit, but they were many (ten in 1900 and thirteen in 1914), and so there was much competition, which kept them small. ${ }^{34}$ The result was a pattern of economic growth which owed more to the rationalization of agriculture than to industrialization.

\footnotetext{
${ }^{33}$ For instance, an attempt to set up a large joint-stock industrial credit bank in Moscow in the 1860 s failed because investors feared to 'offend the authorities.'

${ }^{34}$ Joint-stock Russian banks totalled 40 in 1893, and 50 in 1914, Crisp (1967), p.197.
} 
Spain in the second half of the nineteenth century represents another case which illustrates the consequences of repressing the activity of industrial banks. While incorporation was initially subject to governmental approval, it was liberalized after 1856, leading to the creation of several banks. By 1870 about 30 credit companies and issue banks had appeared, and had engaged in commercial banking (Tortella (1972), p.93). Four of these became quite large. However, they shunned investment in manufacturing firms because of constraints the government posed on their actions, curtailing their ability to invest in manufacturing, and encouraging purely speculative investments in railroads and mining companies. Tortella (1972) forcefully argues that the government's policy impeded a rapid and stable economic growth. In particular, the government prevented banks from effectively coordinating complementary activities: its policy of subsidization of railways while restricting the growth of manufacturing meant that there were not enough goods to transport, and therefore too little business for the railways to be profitable. In this environment, banks had not enough power, nor incentives, to engage in investment coordination.

Interestingly, the Italian experience before 1890 also lends support to our interpretation. Polsi (1996) describes how a large number of small banks competed for financing industry since the 1860s. They extended little equity finance, and competed also with the six banks of issue. The situation changed drastically by the mid 1890s. The Banca d'Italia was set-up in 1894, and was conferred a monopoly over note issuing. Existing ind ustrial credit banks collapsed after a period of speculation. The creation of the Banca Commerciale and Credito Italiano, both much larger than any previous ind ustrial credit bank, brought about a very different environment.

In all of the cases we can notice that one common trait shared by these countries in their failures to industrialize: a financial market structure which was not conducive to bank coordination. The example of Italy is also particularly interesting since it uses 'time-serieslike' reasoning as opposed to 'cross-section-like' reasoning to illustrate the insights from our model. Soon after Italy changed its financial structure, its banks started engaging in coordination, as we discussed in Section 2.

\subsection{Political economy issues}

So far, we have shown that size and market power are necessary conditions for banks to perform a catalytic role. However, we have not tried to answer the question of where do these 'strong banks' come from. One potential concern with the analysis is that we have an omitted variable: are 'strong banks' merely the result of 'strong government?' In other words, what are the political economy foundations of our analysis?

Clearly government played a role in the industrialization process. However, we would argue that in the experience of the countries we examined here, government itself cannot be 
credited for being the catalyst to industrialization. ${ }^{35}$ Nor were the 'strong' banks directly created by the government. Nonetheless, there are some interesting interactions between the banks and the government worth noticing. The three episodes of rapid industrialization all occurred in a period of relative political stability. Government therefore can be credited for providing an environment that allowed the catalyst activity to unfold.

While stable governments provided a suitable environment for catalytic activities, the emergence of strong banks should not be attributed to these governments. In Belgium, the emergence of strong banks was mostly a historic coincidence. The Dutch king Wilhem I created the Société Générale shortly before Belgium's independence in 1830. While the King bought a large part of the shares and retained the right to nominate its governor, the bank was fundamentally a private corporation (Chlepner (1926)). The new Belgian government quickly agreed to the founding of a second large bank, the Banque de Belgique, to counterbalance the power of the Société Générale.

In Germany, Kreditbanken were promoted by Privatbankiers who found their partnerships insufficiently capitalized to effectively finance heavy industry. The creation of these 'strong banks' occurred almost in spite of the Prussian government, which was suspicious of new banks for fear of losing control over monetary policy (Riesser (1911)). The earliest Kreditbank, the Schaaffhausen, was born by incorporation of an illiquid large Privatbankier, A. Schaaffhausen \& Co., whose creditors brought the government to grant a joint-stock bank charter only for fear of a financial crisis (Pohl (1982)). Another Kreditbank, the Darmstädter, could not be based in the financial capital of Frankfurt, where other traditionally minded Privatbankiers controlled the city Senate and had just refused another bank charter. The government's opposition to banks also prevented its promoters to set it up in their own town, Köln. Eventually they set it up in Darmstadt, in the neighboring Grand Duchy of Hesse, which was willing to charter an industrial credit bank (Cameron (1956)). It took the Prussian government another twenty years before it accepted joint-stock banks, and only in reaction to their increasing success in neighboring states.

In Italy the initiative to create strong banks came from private bankers and entrepreneurs, with no government interference (Confalonieri (1976), vol. II). The Banca Commerciale was created in 1894 by six German Kreditbanken which wanted to take an active role in exploiting Italy's industrial potential. Their endeavor received no government support, neither from Italy nor from Germany. The Credito Italiano was then the response of private Italian bankers and entrepreneurs. Again the government did not play a role in its creation.

This evidence shows that 'strong banks' are not merely the result of 'strong government.' Once these banks established themselves as leading players in the economy, however, close

\footnotetext{
${ }^{35}$ In the next section, we discuss the case of Korea, where the government took a more active and direct role.
} 
interaction with the government became inevitable. This involved both give and take.

In Belgium thre was a delicate political balance between the large banks and the government. When the government created the Banque Nationale in 1850 it was a deliberate move to take away control of monetary policy from the Société Générale and the Banque de Belgique. Even within the Société Générale there was a delicate task of balancing political influence. The board of the Société Générale maintained a bipartisan structure, where both leading parties maintained board seats, irrespectively of which party was currently in power (Chlepner (1930)). In Germany Kreditbanken could sometime exert pressure on the government, often asking for protection and support for their clients. They pursued favorable charter conditions for clients who wanted to incorporate, and diplomatic assistance to their clients in the export sector (Riesser (1911)). In Italy, the board members of Banca Commerciale and Credito Italiano spent considerable time and energy in dealing with the government when engineering financial operations involving large companies, as reported in several instances by Confalonieri $(1976,1982)$. This behavior represented an instance of mutual control and influence between banks and government.

Aspects of political economy are therefore important for understanding the role of banks as catalysts for industrialization in emerging markets, and deserve further attention. An important task for future research is to better understand the political economy of how a private institution engaging in industrial promotion interacts with government in the process of industrialization.

\subsection{Alternative catalysts for industrialization}

To round off our discussion of the view of Gerschenkron and Schumpeter, it is worthwhile to briefly mention two further qualifications of our argument, a full development of which is beyond the scope of this paper. First, private banks are one possible solution to the coordination problem, but they are by no means the only possible one. Second, coordination may not even be the problem hampering industrialization.

We have seen that the main argument of Gerschenkron and Schumpeter revolves around the successful industrialization of a number of continental European countries with the assistance of few large universal banks with market power. We have also seen that in some other countries the absence of such banks coincides with protracted delays of industrialization. In a number of other emerging markets, however, institutional mechanisms other than private banks have been used for the coordination of investments.

First, large firms or industrial groups - conglomerates - may exploit complementarities internally (see Khanna (2002)). Probably the most interesting case in this respect is Japan before World War II. Fruin (1992) and Morikawa (1992), among others, document the role

of the Zaibatsus in fostering and coordinating industrialization. Zaibatsus were family- 
dominated conglomerates centered around a trading company which commercialized the products of member firms. Therefore Zaibatsus grew by focusing on 'trading' complementarities among their own companies. Their pattern of development thus contrasted with the European cases of bank coordinated growth, which relied on the exploitation of technological complementarities across industrial sectors. Interestingly, in the pre-war period Japanese regulations forced banks to limit their action to short-term lending and also limited the size and power of its banking institutions (see Patrick (1967)).

A second alternative is government coordination. A country that exemplifies this well is Korea. The Korean government of General Park implemented a coordinated allocation of resources for industrialization which led to a quick industrialization during the 1960s and 1970s, as described by Cho (1989) and Wade (1986). To implement the coordination of investment the government obviously still needs some implementing agent. In the case of Korea, the government nationalized all banks and used them as instruments of economic policy, especially in connection with subsidized credit directed to target sectors, as examined by Cho and Hellmann (1994).

The view of Gerschenkron and Schumpeter applies only to economies that suffer from a coordination problem. Our theory is therefore explicitly targeted at examining how banks can coordinate industrial investments. Coordination is likely to be most important for 'catch-up' economies, and, as argued forcefully by Matsuyama (1995b), it becomes less important as the economy approaches the 'technological frontier.' The best example of an economy that is believed to have industrialized near the technological frontier is, of course, Britain, which led the first Industrial Revolution. Acemoglu and Zilibotti (1997) hold that experimentation and risk diversification were the crucial problems Britain had to solve to become the first country to industrialize. They argue that the fragmented British banking sector was actually instrumental for sustaining experimentation and diversification. Clearly, this fragmented structure also implied that the necessary conditions for bank coordination were not satisfied. Also the industrialization of the United States during the latter part of the eighteenth century owed little to industrial credit banks, whose development was restricted by tight regulation (Roe (1994)). However, in the US case the size of the internal market and the geographic extension of the economy made its industrialization very different from that of Britain or of continental Europe. Indeed, Chandler (1977) shows that, because of its unique geography, the development of railways provided a focal point for the development of the US industrial structure.

\subsection{Testable hypotheses}

We begin our paper with a historical motivation, which contains the puzzling observation that banks seems to have played a catalytic role in the industrialization of some countries, 
but not of others. We then develop a theoretical model that explains under what conditions we can expect banks to play such a role of catalyst. The model provides a conceptual framework that helps us to better understand the historical evidence and to assess its interpretation by Schumpeter and Gerschenkron. But our model also yields interesting empirical predictions that could be tested empirically.

A first prediction of the model is that higher banking concentration favors industrialization. Our analysis in sections 2 and 4.1 provides anedoctal historic evidence which is consistent with this hypothesis. A second prediction of the model that is also consistent with this evidence is that while concentration in banking favors growth in the early stages of industrialization, in later stages it can also lead to a stronger industrial concentration.

Formal econometric tests could be developed to confront these predictions with empirical evidence. For example, one could employ either industry segments or countries as the unit of analysis. For younger industries (or less industrialized countries) we would expect a positive relationship between banking concentration and industrial growth. Related to this, we would also expect a positive relationship between banking concentration and innovation, which might be measured with patents or R\&D expenditure, or between banking concentration and firm natality rates. For more mature industries (or more industrialized countries), we would expect a positive relationship between banking concentration and industrial concentration. This higher industrial concentration may also lead to less innovation, lower firm natality, and lower industrial growth.

In a recent paper, Cetorelli and Gambera (2001) perform some closely related tests. They do not look at industrialization per se, but instead use data from 36 manufacturing industries in 41 industrialized countries over the 1980-1990 period. Their findings are supportive of our hypotheses. Indeed, their main result is that concentrated banking is associated with higher growth rates in industries with younger firms, whereas it is associated with lower growth rates in industries with more established firms. Also the results of Beck and Levine (2002) conform to the predictions of our theory. They find that firm natality rates increase with financial development, so that one should observe increased enterprise formation once catalytic banks start operating, but a slowdown once their efforts to retard financial development unfold.

There may be several reasons why concentrated banking leads to such a pattern of industrial growth. Petersen and Rajan (1995), for example, argue that financing a new firm entails risks that can only be compensated in an on-going relationship. Too much competition may undermine relationship banking if it makes it too easy for a successful firm to exit a relationship.

Such a relationship-based explanation is complementary to ours. The main difference is that our approach does not rely on the interaction of one bank with one firm. Our theory 
thus provides a 'macro' perspective and looks at bank portfolios, rather than at individual relationships. In the relationship model, if a bank incurs initial investment losses, it needs to later recover those from the same client. In our model, however, it is possible that the bank makes losses on some clients, as long as these investments help the bank to make profits from investments in other clients with complementary businesses.

Our macro perspective allows us to derive some additional empirical implications beyond those already tested by Petersen and Rajan. In particular, it predicts that the portfolios of the large catalytic banks should differ systematically from those of the other smaller banks. Smaller industrial banks should in fact have well-diversified portfolios across industries. The larger industrial banks, however, should have portfolios that are concentrated on a set of firms which share significant externalities. Such a portfolio is likely to be less diversified. Our model also predicts that large banks should invest in a large number of industry pioneers, as opposed to industry followers. Moreover, because of the losses from investments in a critical mass of pioneers, the larger industrial banks should be less profitable than their smaller competitors.

Some recent empirical work on the role of German Kreditbanken, surveyed by Edwards and Ogilvie (1996) and Guinnanne (2001), looks at the later stages of German industrialization, i.e the period from 1880 to 1914 . This work provides some preliminary evidence that supports the predictions of the model. Edwards and Ogilvie (1996), for instance, note that, as the German economy grew, Kreditbanken remained heavily specialized in industrial finance and did not branch out into other fast growing segments of the financial market such as, for example, private mortgages. Indeed, in 1900 Kreditbanken still accounted for only $17 \%$ of the financial sector (Goldsmith (1969), p.514). Also, Kreditbanken focussed mostly on joint stock companies (Aktiengesellschaften), a category which constituted only a relatively small share in overall industrial capital: 10\% in 1880 and 16\% in 1900 (Hoffman (1965, p.785)). ${ }^{36}$ While this evidence is suggestive, our theory provides a framework for more conclusive formal tests to be carried out in future analyses of the portfolio structures of these banks.

Finally, our model also provides a new set of predictions about the use of equity financing and the role of universal banks. First, our model predicts that universal banks should have

\footnotetext{
${ }^{36}$ The work of Caroline Fohlin also provides some interesting evidence in this respect. Fohlin (1998a) notes that Kreditbanken's clients became less dependent on external finance over time: The ratio of liquid to fixed assets of established joint-stock companies rose from below 30\% in the 1880s to 60\% in 1912 (and from less than $10 \%$ to $50 \%$ for recently listed ones). These findings confirm Wellhöner's (1989) case studies of nine large industrial companies, and Feldenkirchen's $(1982,1985)$ accounts of financing patterns in heavy industries. Moreover, Fohlin (1998b) shows that firms which borrowed from Kreditbanken did not benefit from lower liquidity constraints than other firms. In her sample of 75 firms listed on the Berlin stock exchange between 1880 and 1913, bank-attached firms were at times more dependent on cash flow for the financing of their investment than bank-independent firms. Fohlin (1998c) finds similar results for a sample of 170 Italian firms financed by the Banca Commerciale Italiana between 1903 and 1911.
} 
a competitive advantage over banks that are restricted to pure loan financing, especially in new industries that require some kind of catalytic coordination. One could then test whether such industries develop faster in emerging markets which allow universal banking. The model also predicts that the minimum size of a catalytic bank is lower if the bank can make equity investments. As a consequence, the relationship between banking concentration and industrial growth should be less pronounced in cases where banks are allowed to hold equity.

\section{Conclusion}

In this paper we provide a new theory of the role of banks as catalysts for industrialization in emerging economies. Our theory formalizes the view of Gerschenkron, Schumpeter and others who studied the industrialization of some continental European countries. We introduce banks into a model of the big push to examine under what circumstances profitmotivated banks would engage in the coordination of industrial investments. The model establishes a theoretical link between the role of banks as catalysts for industrialization and the necessity of market power for these banks. A potential cost of catalytic banks, however, is excessive industrial concentration. The theory also shows why universal banking helps to reduce the (endogenous) cost of coordination, thus improving the efficiency of banks as catalysts. We use the model to interpret a diverse set of observations on the role of banks in the industrialization of emerging economies. We show that in cases where banks took an active role in promoting industrialization we also find that the necessary conditions derived form theory - most notably market power in banking - are satisfied. We also discuss a number of cases where the lack of industrialization seems at least in part related to a violation of these necessary conditions. These examples help sharpen our understanding of when the Gerschenkron-Schumpeter view does or does not apply. We then consider some alternative catalysts, such as the government or industrial conglomerates. Finally, we spell out several predictions of the model which can be formally tested.

The debate about the role of banks in industrialization is not merely a historical issue, but central to the debate about the role of banks in emerging markets. On the one hand, our analysis highlights the importance of a creative role of banks. It reminds us that in some of the most successful emerging economies, banks played a creative role in the promotion of new industries. On the other hand, our analysis also warns against some of the potential costs. In particular, it shows that the very conditions necessary to allow private banks to promote coordinated investments - namely size and market power - also imply an inefficient oligopolistic market structure, which may foster industrial concentration and retard growth once coordination has been achieved. 


\section{References}

[1] Acemoglu, Daron, and Fabrizio Zilibotti [1997], 'Was Prometeus Unbound by Chance? Risk, Diversification and Growth,' Journal of Political Economy, 105 (4), 709-52.

[2] Aghion, Philippe, Mathias Dewatripont, and Patrick Rey [1999], 'Agency Costs, Firm Behavior and the Nature of Competition,' CEPR Discussion Paper n.2130.

[3] Aleotti, Alessandro [1990], Borsa e Industria: 1861-1989, Milano, Edizioni di Comunità.

[4] Allen, Franklin, and Douglas Gale [1998], 'Financial Markets, Financial Intermediaries and Intertemporal Smoothing,' Journal of Political Economy, 105 (107), 523-546.

[5] Aoki, Masahiko, and Hugh Patrick [1994], 'The Japanese Main Bank System,' Oxford, Oxford University Press.

[6] Bairoch, Paul [1976a], 'Europe's Gross National Product: 1800- 1975,' Journal of European Economic History, 5 (2) 273-40.

[7] Bairoch, Paul [1976b], Commerce extérieur et développement économique de l'Europe au XIX siècle, Paris, École des Hautes Études en Science Sociales.

[8] Bairoch, Paul [1982], 'International Industrialization Levels from 1750 to 1980,' Journal of European Economic History, 11 (1) 269-333.

[9] Beck, Thorsten, and Ross Levine [2001], 'Industry Growth and Capital Allocation: Does Having a Market- or Bank-Based System Matter?' Journal of Financial Economics, forthcoming.

[10] Beer, John [1959], 'The Emergence of the German Dye Industry,' Urbana, The University of Illinois Press.

[11] Bencivenga, Valerie, and Bruce Smith [1991], 'Financial Intermediation and Endogenous Growth,' Review of Economic Studies, 58 (2), 195-209.

[12] Benston, George [1994], 'Universal Banking,' Journal of Economic Perspectives, 8 (3), $121-43$.

[13] Bhattacharya and Thakor [1993], 'Modern Banking Theories,' Journal of Financial Intermediation, 3 (1), 2-50.

[14] Cameron, Rondo [1956], 'Founding the Bank of Darmstadt,' in Explorations in Economic History, 8 (3), 113-30. 
[15] Cameron, Rondo [1961], France and the Economic Development of Europe, Princeton, Princeton University Press.

[16] Cameron, Rondo (ed.) [1967], Banking in the Early Stages of Industrialization: A Study in Comparative Economic History, Oxford, Oxford University Press.

[17] Cameron, Rondo (ed.) [1972], Banking and Economic Development, New York, Oxford University Press.

[18] Cetorelli, Nicola and Michele Gambera [2001], 'Banking Market Structure, Financial Dependence and Growth: International Evidence from Industry Data,' Journal of Finance, 56 (2), 617-48.

[19] Chandler, Alfred [1977], The Visible Hand: The Managerial Revolution in American Business, Cambridge, MA, The Belknap Press.

[20] Chlepner, Bernard [1926], La Banque en Belgique: étude historique et économique, Bruxelles, Lamertin.

[21] Chlepner, Bernard [1930], Le marché financier belge depuis cent ans, Bruxelles, Falk.

[22] Chlepner, Bernard [1943], Belgian Banking and Banking Theory, Washington D.C., The Brookings Institution.

[23] Cho, Yoon Je [1989], 'Finance and Development: The Korean Approach,' Oxford Review of Economic Policy, 5 (4), 221-37.

[24] Cho, Yoon Je, and Thomas Hellmann [1994], 'The Government's Role in Japanese and Korean Credit Markets: A New Institutional Economic Perspective,' Seoul Journal of Economics, 7 (4), 383-415.

[25] Cohen, Jon [1967], 'Financing Industrialization in Italy, 1894-1914: The Partial Transformation of a Late-Comer,' Journal of Economic History, 27 (3), 363-82.

[26] Cohen, Jon [1972], 'Italy 1861-1914', in Rondo Cameron (ed.) Banking and Economic Development, New York, Oxford University Press, p.58-91.

[27] Confalonieri, Antonio [1976], Banca e Industria in Italia, 1894-1906, Milano, Banca Commerciale Italiana.

[28] Confalonieri, Antonio [1982], Banca e Industria in Italia dalla crisi del $190^{\prime}$ all'agosto 1914, Milano, Banca Commerciale Italiana. 
[29] Crisp, Olga [1967], 'Russia,' in Rondo Cameron (ed.) Banking in the Early Stages of Industrialization: A Study in Comparative Economic History, Oxford, Oxford University Press, p.183-238.

[30] Da Rin, Marco [1996], 'Understanding the Development of German Kreditbanken, 1850-1914: an Approach from the Economics of Information,' Financial History Review, 3 (1) 29-47.

[31] Da Rin, Marco [1998], 'Finance and the Chemical Industry,' in Ashish Arora, Ralph Landau, and Nathan Rosenberg (eds.) Chemicals and Long-term Economic Growth, New York, John Wiley \& Sons.

[32] Diamond, Douglas [1984], 'Financial Intermedation and Delegated Monitoring,' Review of Economic Studies, 51 (4), 393-414.

[33] Dinç, Serdar [2000], ' Bank reputation, bank commitment, and the effects of competition in credit markets,' Review of Finanacial Studies, 13 (3), 781-812.

[34] Durviaux, Roland [1947], La banque mixte, origine et soutien de l'expansion économique de la Belgique, Bruxelles, Bruylant.

[35] Edwards, Jeremy, and Sheilagh Ogilvie [1996], 'Universal Banks and German Industrialization: A Reappraisal,' Economic History Review, 49 (3), 427-46.

[36] Fama, Eugene [1980], 'Banking in the Theory of Finance,' Journal of Monetary Economics, $\mathbf{5}^{‘}(2), 29-39$.

[37] Federico, Giovanni, and Gianni Toniolo [1991], 'Italy', in Richard Sylla and Gianni Toniolo (eds.) Patterns of European Industrialization, London, Routledge.

[38] Feldenkirchen, Wilfried [1982], Die Eisen- und Stahlindustrie des Ruhrgebiets, 18791914: Wachstum, Finanzierung und Struktur ihrer Grossunternehmen, Wiesbaden.

[39] Feldenkirchen, Wilfried [1985], 'Zur Finanzierung von Grossunternehmen in der chemischen und elektrotechnischen Industrie Deutschlands vor dem Ersten Weltkrieg,' in Richard Tilly (ed.) Beiträge zur quantitativen vergleichenden Unternehmengeschichte, Stuttgart, 94-125.

[40] Feldenkirchen, Wilfred [1991], 'Banking and Economic Growth: Banks and Industry in Germany in the Nineteenth Century and their changing Relationship during Industrialization,' in Wang Lee (ed.) German Industry and German Industrialization, London, Routledge. 
[41] Fohlin, Caroline [1998a], 'Universal Banking in Pre-World War I Germany: Model or Myth?' Explorations in Economic History, 36 (4), 305-43.

[42] Fohlin, Caroline [1998b], 'Relationship Banking, Liquidity, and Investment in the German Industrialization,' Journal of Finance, 53 (5), 1737-58.

[43] Fohlin, Caroline [1998c], 'Fiduciari and Firm Liquidity Constraints: The Italian Experience with German-style Universal Banking,' Explorations in Economic History, 35 (1), 83-107.

[44] Fruin, Mark [1992], The Japanese Enterprise System, Oxford, Clarendon Press.

[45] Fuà, Giorgio [1965], Notes on Italian Economic Growth, 1861-1964, Milano, Giuffrè.

[46] Gale, Douglas, and Martin Hellwig [1985], 'Incentive-Compatible Debt Contracts: The One-Period Problem,' Review of Economic Studies, 52 (3), 647-63.

[47] Gerschenkron, Alexander [1962], Economic Backwardness in Historical Perspective, Cambridge, Harvard University Press.

[48] Goldsmith, Raymond [1969], Financial Structure and Development, New Haven, Yale University Press.

[49] Guinnanne, Timothy, [2001], 'The Development of Germany's Banking System,' Journal of Economic Literature, forthcoming.

[50] Haber, Stephen [1991], 'Industrial Concentration and the Capital Markets: A Comparative Study of Brazil, Mexico, and the United States, 1830-1930,' Journal of Economic History, 51 (3), 559-80.

[51] Harris, Milton and Arthur Raviv [1991], 'The Theory of Capital Structure,' Journal of Finance, 46 (1), 297-356.

[52] Hart, Oliver [1983], 'The Market Mechanism as an Incentive Scheme,' Bell Journal of Economics, 14 (2), 366-82.

[53] Hart, Oliver, and John Moore [1995], 'Debt and Seniority: An Analysis of the Role of Hard Claims in Constraining Management,' American Economic Review, 85 (3), $567-85$.

[54] Hellmann, Thomas and Manju Puri [2000], 'The Interaction between Product Market and Financing Strategy: The Role of Venture Capital,' Review of Finanacial Studies, 13 (4) 959-84. 
[55] Hellmann, Thomas and Manju Puri [2002], 'Venture Capital and the Professionalization of Start-ups: Empirical Evidence,' The Journal of Finance, 57 (1).

[56] Hoffmann, Walter [1965], Das Wachstum der Deutschen Wirtschaft seit der Mitte des 19. Jahrhunderts, Berlin, Springer Verlag.

[57] Jeidels, Otto [1905] Das Verhaltnis der deutschen Grossbanken Zur Industrie, Leipzig, Duncker \& Humblot

[58] Kaplan, Steven, and Per Strömberg [2000], 'Financial Contracting Theory Meets the Real World: An Empirical Analysis of Venture Capital Contracts,' CEPR Discussion Paper 2421.

[59] Khanna, Tharun [2002] 'Business Groups and Social Welfare in Emerging Markets: Existing Evidence and Unanswered Questions,' forthcoming, European Economic Review.

[60] King, Robert, and Ross Levine [1993], 'Finance and Growth: Schumpeter Might be Right,' Quarterly Journal of Economics, 108 (3), 681-737.

[61] Lerner, Joshua, and Robert Merges [1998], 'The Control of Technology Alliances: An Empirical Analysis of the Biotechnology Industry,' Journal of Industrial Economics, 46, 125-156.

[62] Levine, Ross [1997], 'Financial Development and Economic Growth: Views and Agenda,' Journal of Economic Literature, 35 (2), 688-726.

[63] Levine, Ross and Sara Zervos [1998], 'Stock Markets, Banks, and Economic Growth,' American Economic Review, 88 (3).

[64] Lévy-Leboyer, Maurice [1964], Les Banque Europèenes et l'Industrialization Internationale dans la Première Moitié du XIX Siècle, Paris, Presse Universitaire de France.

[65] Matsuyama, Kiminori [1995], 'Complementarities and Cumulative Processes in Models of Monopolistic Competition,' Journal of Economic Literature, 33 (2), 701-29.

[66] Matsuyama, Kiminori [1995b], 'New Goods, Market Formations, and Pitfalls of System Design,' Journal of the Japanese and International Economies, 9 (3), 376-402.

[67] Milgrom, Paul, and John Roberts [1990], 'The Economics of Modern Manufacturing: Technology, Strategy and Organization,' American Economic Review, 80 (3), 511-28.

[68] Milgrom, Paul, and John Roberts [1994a], 'Complementarities and Systems: Understanding Japanese Economic Organization,' Estudios Económicos, 9 (1), 3-42. 
[69] Milgrom, Paul, and John Roberts [1994b], 'Comparing Equilibria,' American Economic Review, 84 (3), 441-59.

[70] Milgrom, Paul, and Chris Shannon [1994], 'Monotone Comparative Statics,' Econometrica, 62 (1), 157-180.

[71] Mitchell, Brian [1980], European Historical Statistics, London, Macmillan

[72] Morikawa, Idemasa [1992], Zaibatsus, Tokyo, Tokyo University Press.

[73] Morrison, Rodney [1967], 'Financial Intermediaries and Economic Development: The Belgian Case,' Scandinavian Economic History Review, 19 (1), 56-70.

[74] Motschmann, Gustav [1915] Das Depositengeschaft Der Berliner Grossbanken, München, Duncker \& Humblot.

[75] Murphy, Kevin, Andrei Shleifer and Robert Vishny [1989], 'Industrialization and the Big Push,' Journal of Political Economy, 97 (5), 1003-1026.

[76] Neuville, Jean [1974], L'évolution des Rélations Industrielles en Belgique, Bruxelles, Editions Vie d'Ouvrier.

[77] Patrick, Hugh [1967], 'Japan,' in Rondo Cameron (ed.) [1967], Banking in the Early Stages of Industrialization: A Study in Comparative Economic History, Oxford, Oxford University Press, p.239-89.

[78] Petersen, Mitchell, and Raghuram Rajan [1995], 'The effect of credit market competition on lending relationships,' Quarterly Journal of Economics, 110 (1), 407-43.

[79] Pohl, Manfred [1982],'Die Entwicklung des Deutschen Bankenwesens zwischen 1848 und 1870,' in G. Ashauer (ed.) Deutsche Bankengeschichte, Band 2, Fritz Knapp Verlag, Frankfurt a.M..

[80] Polsi, Alessandro [1996], 'Financial Institutions in Nineteenth Century Italy: The Rise of a Banking System,' Financial History Review, 3 (2), 117-38.

[81] Rajan, Raghuram [1992], 'Insiders and Outsiders: The Choice Between Informed and Arms'-Length Debt,' Journal of Finance, 47 (4), 1367-1400.

[82] Riesser, Jacob [1911], The Great German Banks, Washington, D.C., National Monetary Commission.

[83] Rajan, Raghuram, and Luigi Zingales [1998], 'Financial Dependence and Growth,' American Economic Review, 88 (3), 559-86. 
[84] Roe, Mark [1994], Strong Managers, Weak Owners, Princeton, Princeton University Press.

[85] Romeo, Rosario [1972], Breve storia della grande industria in Italia, Bologna, Cappelli.

[86] Schumpeter, Joseph [1934], The Theory of Economic Development, Cambridge, MA, Harvard University Press.

[87] Schumpeter, Joseph [1939], Business Cycles, New York, McGraw-Hill.

[88] Segal, Ilya [1999], 'Contracting with Externalities,' Quarterly Journal of Economics, $114(2), 337-388$.

[89] Société Générale de Belgique [1922], Le Centenaire de la Société Générale, Bruxelles, Société Générale.

[90] Stiglitz, Joseph [1985], 'Credit Markets and the Control of Capital,' Journal of Money, Credit, and Banking, 17 (2), 133-52.

[91] von Thadden, Ernst-Ludwig [1995], 'Long-term Contracts, Short-term Investment and Monitoring,' Review of Economic Studies, 62 (95), 555-75.

[92] Tilly, Richard [1966a] Financial Institutions and Industrialization in the Rhineland 1815-1870, Madison, The University of Wisconsin Press.

[93] Tilly, Richard [1966b], 'Germany, 1815-70' in Rondo Cameron (ed.) Banking in the Early Stages of Industrialization: A Study in Comparative Economic History, Oxford, Oxford University Press.

[94] Tilly, Richard [1983], 'Mergers, External Growth, and Finance in the Development of Large Scale Enterprise in Germany, 1880-1913,' Journal of Economic History, 42 (3), 629-58.

[95] Tilly, Richard [1993], 'On the Development of German Big Banks as Universal Banks in the 19th and 20th Century: Engine of Growth or Power Block?', German Yearbook of Business History, 109-30.

[96] Toniolo, Gianni [1988], Storia economica dell'Italia liberale, Bologna, Il Mulino.

[97] Tortella, Gabriel [1972], 'Spain,' in Rondo Cameron (ed.) Banking and Economic Development, New York, Oxford University Press, p.91-121.

[98] Wade, Robert [1990], Governing the Market, Princeton, Princeton University Press. 
[99] Wee, Herman van der [1981], 'La strategie d'investissement des entreprises belges et son influence sur le developpement économique de l'Europe,' International Review of the History of Banking, 22 (1), 1-22.

[100] Wellhöner, Werner [1989], Grossbanken und Grossindustrie im Kaiserreich, Göttingen, Vandenhoeck \& Ruprecht. 
Figure 1

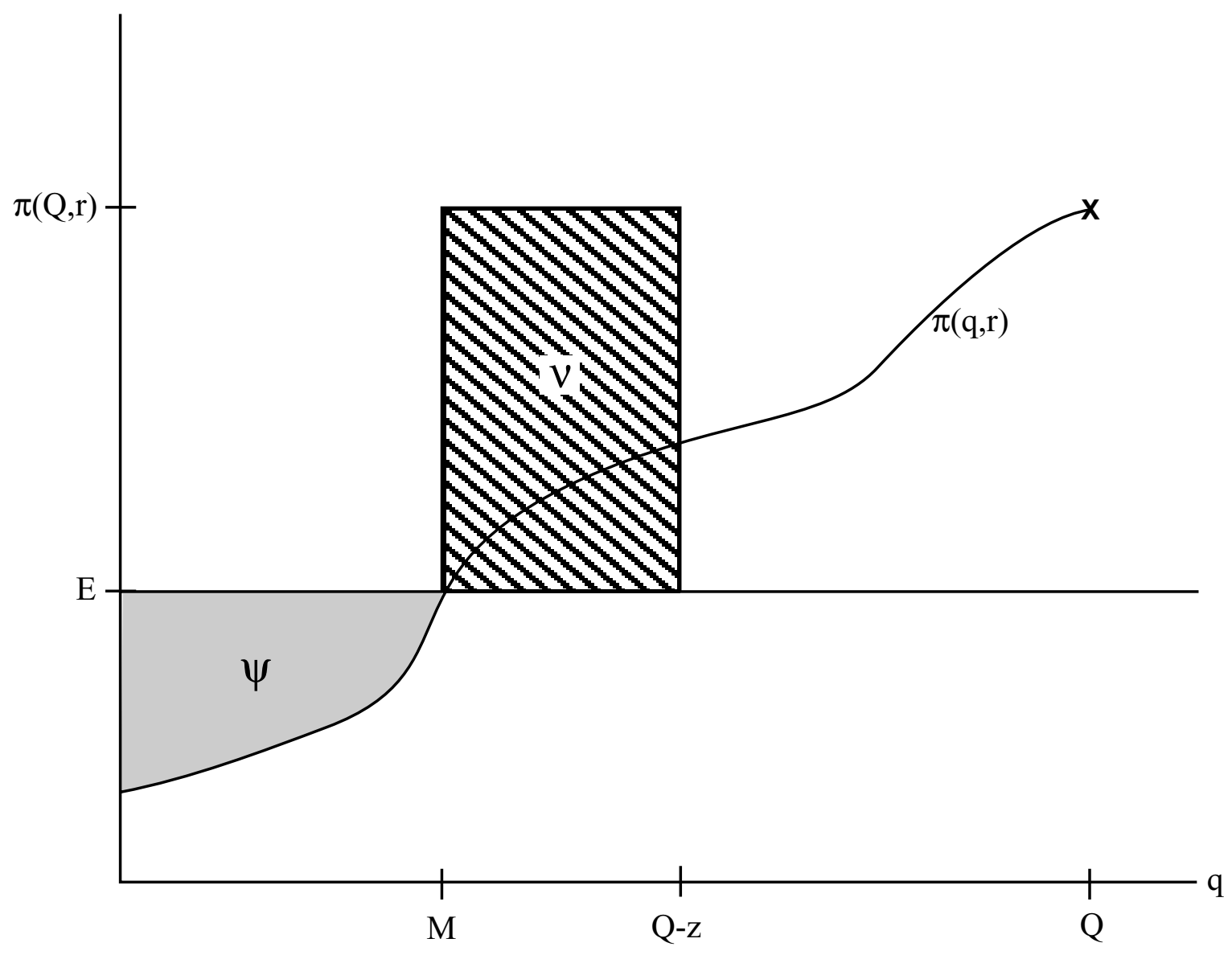




\section{Appendix}

\section{Proof of Proposition 2}

(i) Since each entrepreneur needs to borrow the same amount of capital, contracts differ only with respect to the interest rates. Suppose $L$ offers a set of debt contracts $\left\{i_{q}\right\}$ to entrepreneurs $q=1, \ldots, M$, that satisfies $\pi\left(q, i_{q}\right)=W$. The interest rate on each contract $i_{q}$ is chosen so that if all entrepreneurs with a lower $q$ start a venture, then entrepreneur $q$ also finds it worthwhile to do so. Thus each entrepreneur in the critical mass is offered a different contract. Choose $i_{1}$ such that $\pi\left(1, i_{1}\right)=W$. Then, entrepreneur $q=1$ always starts a firm, irrespective of other entrepreneurs' decisions. Entrepreneur $q=2$ knows this. Then choose $i_{2}$ such that $\pi\left(2, i_{2}\right)=W$. Entrepreneur $q=2$ thus starts a new firm irrespective of what entrepreneurs $q=3, \ldots, Q$ do. Similarly for entrepreneur $q=3, \ldots, M$. With this inductive chain we find that all entrepreneurs $q=1, \ldots, M$ start a venture. Note that this is a simultaneous move game: The optimal offer of $L$ does not rely on sequential moves, but only on a consistent chain of beliefs. Once $M$ entrepreneurs start ventures, all other entrepreneurs - by definition - find it worthwhile to do so as well. Therefore the only equilibrium left is the $E M E$, where all entrepreneurs, $q=1, \ldots \ldots Q$ start a venture. $L$ is thus a catalyst for emerging markets.

The next step is to show that while $\left\{i_{q}\right\}$ allows $L$ to induce coordination, it makes it costly for $L$ to act as a catalyst. Consider an alternative set of contracts that has exactly one interest rate higher than in the set $\left\{i_{q}\right\}$. Denote the different contract $i_{q}^{\prime}$, which is offered to some entrepreneur $q^{\prime}$. We know that $\left\{i_{q}^{\prime}\right\}$ is such that all entrepreneurs with $q<q^{\prime}$ always start a venture. Now entrepreneur $q^{\prime}$ will do so only if at least some other entrepreneurs with $q>q^{\prime}$ do - as the interest rate $i_{q}^{\prime}$ is too high to make a new venture attractive otherwise. This implies multiple equilibria: If all entrepreneurs with $q>q^{\prime}$ expect entrepreneur $q^{\prime}$ not to start a venture, they will not do so either. This creates a self-fulfilling belief which makes it optimal for $q^{\prime}$ not to start a venture. Obviously, if all entrepreneurs with $q>q^{\prime}$ expect entrepreneur $q^{\prime}$ to start a venture, they will form a positive self-fulfilling belief, which makes it optimal for $q^{\prime}$ to start a venture. In this case the EME occurs. But if $L$ raises the interest rates it charges on even only one contract, not starting a new venture remains a possibility, and thus coordination-defined by the elimination of the $S Q E$ - is not achieved. This proves that $\left\{i_{q}\right\}$ is the most profitable set of contracts $L$ is able to offer in order to induce coordination. But since $\pi(M, r)<W$, and $i_{q} \leq r$ for all $q=1, \ldots, M$, the latter inequality must be strict for at least one $q$. Therefore, $L$ does not earn a profit on any of these loans, and takes a loss on at least one of them. Formally, using $\pi\left(q, i_{q}\right)=\beta\left[f(q)-\left(1+i_{q}\right) X\right]=W$, we get: 


$$
\psi=\sum_{q=1}^{M} \beta\left(1+i_{q}\right) X-X=\sum_{q=1}^{M} \beta f(q)-F<0
$$

(ii) In order for $L$ to offer the contract $\left\{i_{q}\right\}$, it must be overall profitable to do so: $\rho^{L}=\nu+\psi \geq 0$. The value of $\nu$ is determined by market clearing. The interest rate charged to entrepreneurs outside the critical mass, say $i_{z}$, is determined by the condition $\pi\left(Q, i_{z}\right)=W$, and it is the same whether the lender is $L$ or one of the investors in the competitive fringe. In this simple model with homogeneous entrepreneurs investors extract all the rents from coordination, as long as $z<Q-M$. Since $\pi(Q, r)>W$ by assumption, it follows that $i_{z}>r$, and $\nu=(Q-M-z)\left[\beta\left(1+i_{z}\right) X-X\right]=(Q-M-z)[\beta f(Q)-F]$. It follows that there exists a critical level $\widehat{z}<Q-M$, such that $L$ offers $\left\{i_{q}\right\}$ if and only if $z<\widehat{z}$.

(iii) Entrepreneurs in the critical mass all pay a cost of capital lower than the market rate, i.e., $i_{q}<r$, but outside the critical mass entrepreneurs face a cost of capital higher than the market rate $i_{z}>r$. Since $L$ makes non-negative profits $\rho^{L}$ by lending $X$ to $(Q-z)$

entrepreneurs, its entrepreneurs face an average cost of capital equal to $r+\frac{\rho^{L}}{(Q-z) X} \geq r$. Moreover, the entrepreneurs financed by investors in the competitive fringe pay a cost of capital equal to $i_{z}>r$. Therefore the average cost of capital to entrepreneurs is strictly higher than $r$.

\section{Proof of Proposition 3}

(i) - (iii) If $L$ finances an entrepreneur $q$ by holding a share $\alpha$ of its equity in addition to a loan, then the entrepreneur's profit is given by:

$$
\pi(K, i, \alpha)=\beta(1-\alpha)[(f(K)-(1+i) X]
$$

and L's (net) profit by:

$$
\rho_{q}=\beta \alpha[(f(K)-(1+i) X]+\beta(1+i) X-X
$$

As in the case with pure debt contracts, in order to achieve coordination, $L$ needs to offer a set of contracts $\left\{i_{q}, \alpha\right\}$ that will induce all entrepreneurs in the critical mass to start a venture, i.e., $\pi\left(q, i_{q}, \alpha\right)=W$ for all $q=1, \ldots, M$. The proof that investor coordination is feasible is then the same as before. We then show that equity finance makes coordination less costly. From $\pi\left(q, i_{q}, \alpha\right)=W$ we get $\beta(1-\alpha)\left(1+i_{q}\right) X=\beta(1-\alpha) f(q)-W$, so that we can write $\rho_{q}=\beta \alpha f(Q)+\beta(1-\alpha) f(q)-W-X=(\beta f(q)-F)+\alpha \beta(f(Q)-f(q))$. The first term is negative and represents the loss the investor suffers from financing entrepreneurs in 
the critical mass. The second term is positive and represents the profit from holding equity and sharing in the appreciation of entrepreneurs' value as coordination shifts beliefs from pessimistic $(K=q)$ to optimistic $(K=Q)$. It is immediate that the larger $\alpha$ the larger is this second term, and so the lower is the cost of coordination $\psi$. In turn, the lower the coordination cost $\psi$, the larger $\widehat{z}$ - the largest size of the competitive fringe which makes coordination by $L$ feasible. For firms outside the critical mass, $L$ extracts all the profits as in the case of pure debt contracts. Hence, $\rho^{L}$ increases monotonically in $\alpha$ and $L$ will always prefer to finance firms with equity contracts.

$(i v)-(v)$ If there is no limit to the extent of equity that investors can hold, then from (iii) $L$ will finance entrepreneurs only with equity. In this case, the amount of equity $L$ holds in each venture in the critical mass is given by $\beta(1-\alpha) f(q)=W$, so that $\alpha=1-\frac{W}{\beta f(q)}$. $L$ 's (net) profit is then given (after some transformation) by $\rho_{q}^{L}=\beta f(Q)-F-W\left(\frac{f(Q)}{f(q)}-1\right)$. Summing over all $q \in M$, we find that $\psi=M(\beta f(Q)-F)-W \Gamma$, where $\Gamma=\sum_{q=1}^{M}\left(\frac{f(Q)}{f(q)}-1\right)$. We then have $\psi \leq 0$ for $F \leq \widehat{F}=\beta f(Q)-W \frac{\Gamma}{M}$. Note that $\beta f(Q)-\widehat{F}>0$, so that $\psi \leq 0$ is always possible in the feasible range for $F$. Similarly, $\psi \geq 0$ for $E \leq \widehat{W}=\frac{M}{\Gamma}(\beta f(Q)-F)$.

\section{A model with incentive and coordination problems}

Consider the following production function: $f(K, e, \omega)=g(K) e \omega$, where $g(K)$ is an increasing function of $K$ (measuring the complementarity effect), $e$ is the entrepreneur's effort, and $\omega$ is a random variable with distribution - over the interval $[0, \infty)$. Let $c(e)$ be the entrepreneur's private costs of exerting effort, with $c(0)=c^{\prime}(0)=0, c^{\prime}(e)>0$ for $e>0$, $c^{\prime}(e) \rightarrow \infty$ for $e \rightarrow \infty$ and $c^{\prime \prime}<0$ for all $e$, so that the optimal $e$ is bounded away from 0 and $\infty$. Denote the entrepreneur's utility function as:

$$
u_{E}\left(q, \sigma_{q}\right)=\int_{0}^{\infty} \beta\left[f\left(q, e^{*}, \omega\right)-\sigma_{q}\left(f\left(q, e^{*}, \omega\right)\right)\right] d-(\omega)-c\left(e^{*}\right)
$$

where $e^{*}=\operatorname{argmax} u_{E}\left(q, \sigma_{q}\right)$ is chosen to maximize this expression. Similarly, denote the investor's utility function as:

$$
u_{I}\left(q, \sigma_{q}\right)=\int_{0}^{\infty} \beta \sigma_{q}\left(f\left(q, e^{*}, \omega\right)\right) d-(\omega)
$$

where $e^{*}$ is chosen as before to maximize $u_{E}\left(q, \sigma_{q}\right)$. The optimal contract for entrepreneur $q$ in the critical mass maximizes $\rho_{q}^{L}=u_{I}\left(Q, \sigma_{q}\right)-X-t$, subject to $u_{E}\left(q, \sigma_{q}\right)+t=W$, where $t$ is a monetary transfer from $L$ to the entrepreneur. ${ }^{37}$

\footnotetext{
${ }^{37}$ For all the firms outside the critical mass, the optimal contract is simply found by maximizing $\rho_{q}=$ $u_{I}\left(Q, \sigma_{q}\right)-X-t$, subject to $u_{E}\left(Q, \sigma_{q}\right)+t=W$. This simplifies to the standard principal-agent problem of $\operatorname{maximizing} \int_{0}^{\infty} \beta f(Q, e, \omega) d-(\omega)-F-c(e)$.
} 
The optimal security $\sigma_{q}^{*}$ that solves the above maximization problem depends on the distribution of $\omega$, and the private $\operatorname{costs} c(e)$, and may well be highly non-linear. We now show that the main insights of the model are nonetheless preserved:

Proposition 5 If $L$ uses the optimal security $\sigma_{q}^{*}$, then:

(i) for $F$ sufficiently large, inducing coordination is costly: $\psi<0$;

(ii) there exists a critical value $\widehat{z}$ such that $L$ induces coordination if and only if the competitive fringe has size $z<\widehat{z}$.

Proof. We first show that $u_{E}\left(q, \sigma_{q}^{*}\right)<u_{E}\left(Q, \sigma_{q}^{*}\right)$, i.e., that $u_{E}$ increases in $q$. To see why, suppose it does not. This would imply that $u_{E}$ also does not increase in $e$, since $g(K)$ and $e$ increase $f($.$) in the same manner. { }^{38}$ But this would imply $e=0$, and thus $f=0$, which is never optimal.

The above inequality implies that $L$ cannot capture all of the rents from inducing coordination. As a consequence we can find $F$ sufficiently large (while keeping $W$ constant) so that $L$ makes a loss on financing an entrepreneur in the critical mass. Formally, let $u \equiv \int_{0}^{\infty} \beta f(Q, e, \omega) d-(\omega)-c(e)$, then we can find an $F$ such that:

$$
\rho_{q}^{L}=u-\left[u_{E}\left(Q, \sigma_{q}^{*}\right)-u_{E}\left(q, \sigma_{q}^{*}\right)\right]-F<0
$$

By choosing $F$ sufficiently large we can thus ensure that $\psi=\sum_{q=1}^{M} \rho_{q}^{L}<0$. But note that $F$ may be chosen so that $F<u$, so that the $E M E$ is still preferable to the $S Q E$ equilibrium. We have thus shown part $(i)$. Part (ii) follows in the usual way.

Therefore, the model with optimal non-linear contracts and incentives, while being analytically less tractable, closely matches our base model in all important aspects.

\section{A general model of complementarities with heterogeneous firms}

We now present a model with heterogeneous entrepreneurs which allows for a wide variety of complementarities. We show how the insights of our base model carry over to a much more general setting.

We modify the model of the main text by allowing each firm to have a different profitability, and a different impact on other firms' profitability. Let $I_{q}=1$ if an entrepreneur decides to set up a new venture $q$, and $I_{q}=0$ otherwise. Denote the set of all such decisions by $K=\left\{I_{q}\right\}_{q \in Q}$, which forms a sub-lattice. Let $\|K\|$ be the corresponding number

\footnotetext{
${ }^{38}$ While we have chose the simplest possible functional form for $f($.$) , all we need is that it is monotone$ increasing in both $g($.$) and e$.
} 
of entrepreneurs who set up a firm or, equivalently, the number of new firms created. ${ }^{39}$ The (gross) return $f(K)$ for any particular venture $q$ is given by $f(K)$, where $K$ is now a vector. The fundamental assumption we make is that there are non-negative externalities between firms. The most general such assumption is to only stipulate that $f(K)$ is supermodular in $K{ }^{40}$. This implies that for any $K_{1} \subseteq K_{2}$ the returns to firm $q$ are such that: $f\left(K_{1}, q\right) \leq f\left(K_{2}, q\right)$. Using pure debt contracts, the present value of the profits from firm $q$ is given by:

$$
\pi(K, q, i)=\beta[f(K, q)-(1+i) X]
$$

where entrepreneur $q$ expects the set $K \cup q$ of new firms. As in the main text, we assume that all entrepreneurs have the same endowment $W$ and require the same amount of external funding $X=F-W$, although it is straightforward to relax this assumption. Entrepreneur $q$ sets up a new firm whenever $\pi(K, q, i) \geq W$. A set of firms $K$ is a competitive equilibrium if $\pi(K, q, r) \geq W$ for all $q \in K$ and $\pi(K, q, r)<W$ for all $q \in Q \backslash K$. We denote the equilibrium sets of firms by $K^{n}, n=1, \ldots, N$, where $N$ is the number of competitive equilibria.

Proposition 6 (i) With a competitive financial market there may exist multiple equilibria.

(ii) There always exists a 'maximal' equilibrium in which all the entrepreneurs that set up a new firm in at least one equilibrium $K^{n}$ do set up a firm. It Pareto dominates all other equilibria.

(iii) There always exists a 'minimal' equilibrium in which all entrepreneurs that do not set up a new firm in at least one equilibrium $K^{n}$ do not set up a firm. It is Pareto dominated by all other equilibria.

(iv) In the 'maximal' equilibrium there are (weakly) less entrepreneurs setting up a firm than in an utilitarian social welfare optimum.

Proof. ( $i$ ) The possibility of multiple equilibria is established by the example in the main text, and trivially extends to the general case when the simplifying assumptions of identical entrepreneurs and simple complementarity we use in the main text are dropped. The equivalent result is also derived in Milgrom and Roberts (1990a, 1994a, 1994b).

(ii) Consider any two equilibria $K^{i}$ and $K^{j}, i \neq j$ which are not nested, i.e., $K^{i j} \equiv$ $K^{i} \backslash K^{j} \neq \emptyset$, and $K^{j i} \equiv K^{j} \backslash K^{i} \neq \emptyset$. By the definition of equilibrium, for all $q \in K^{i}$ we

\footnotetext{
${ }^{39}$ For a definition and discussion of sub-lattices see Milgrom and Shannon (1994). Notice that our model could be extended to the more general case where entrepreneurs also choose the level of investment, so that $I_{q}$ is an interval rather than a binary function. All that is required is that the set of investment decisions $K$ forms a sub-lattice.

${ }^{40}$ For a definition and discussion of supermodularity, see Milgrom and Roberts (1990, 1994a) and Milgrom and Shannon (1994).
} 
have $\pi\left(K^{i}, q, r\right) \geq W$ so that $\pi\left(K^{i} \cup K^{j}, q, r\right) \geq W$. Similarly, for all $q \in K^{j}$ we have $\pi\left(K^{j}, q, r\right) \geq W$ so that $\pi\left(K^{j} \cup K^{j}, q, r\right) \geq W$. Then there exists some set $K^{n} \supseteq\left(K^{i} \cup K^{j}\right)$ such that $\pi\left(K^{n}, q, r\right) \geq \pi\left(K^{i} \cup K^{j}, q, r\right) \geq W$ for all $q \in\left(K^{i} \cup K^{j}\right)$, and $\pi\left(K^{n}, q, r\right) \geq W$ for all $q \in K^{n}$, and $\pi\left(K^{n}, q, r\right)<W$ for all $q \in Q \backslash K^{n}$. This shows that for any non-nested equilibria there exists an equilibrium $\left(K^{n}\right)$ where all entrepreneurs setting up a firm in either equilibrium do invest as well. We denote the largest such equilibrium by $K^{E M E}$, or simply EME. The EME Pareto dominates all other equilibria since investors make zero profits, the largest number of entrepreneurs are setting up a new firm, and firms can only have a positive externalities on others' profits.

(iii) Consider any two equilibria $K^{i}$ and $K^{j}, i \neq j$ which are not nested, i.e., $K^{i j} \equiv$ $K^{i} \backslash K^{j} \neq \emptyset$, and $K^{j i} \equiv K^{j} \backslash K^{i} \neq \emptyset$. For all $q \in K^{i j}$ we have $\pi\left(K^{j}, q, r\right)<W$. Similarly, for all $q \in K^{j i}$ we have $\pi\left(K^{i}, q, r\right)<W$. Thus, for all $q \in K^{i j} \cup K^{j i}$ we have $\pi\left(K^{i} \cap K^{j}, q, r\right)<W$. The above inequalities imply that there exists some set $\emptyset \subseteq K^{0} \subseteq\left(K^{i} \cap K^{j}\right)$ such that $\pi\left(K^{0}, q, r\right) \leq \pi\left[K^{i} \cap K^{j}, q, r\right)<W$ for all $q \in\left(K^{i j} \cup K^{j i}\right), \pi\left(K^{0}, q, r\right)<W$ for all $q \in Q \backslash K^{0}$, and $\pi\left(K^{0}, q, r\right) \geq W$ for all $q \in K^{0}$. This shows that for any two non-nested equilibria there exists an equilibrium where no entrepreneur in their non-overlapping subsets is included. We denote the smallest such equilibrium by $K^{S Q E}$, or simply $S Q E$. The $S Q E$ is Pareto inferior to all other equilibria since it is the one with the fewest entrepreneurs setting up a new firm.

(iv) There cannot be too many entrepreneurs setting up a firm in $K^{E M E}$ since every entrepreneur is individually profitable, and any one firm can only have positive externalities on all others. Suppose next an entrepreneur $q^{\prime} \in Q \backslash K^{E M E}$ were to set up a firm as well. The definition of $K^{E M E}$ implies that $q^{\prime}$ takes a loss. But by assumption 1 the investment by $q^{\prime}$ (weakly) raises $f\left(K^{E M E}, q, r\right)$ to $f\left(K^{E M E} \cup q^{\prime}, q, r\right)$ for all $q \in K^{E M E}$. Depending on the strength of the complementarity effect, captured by the function $f($.$) , it may be socially$ efficient to have more entrepreneurs setting up a firm than in $K^{E M E}$.

We now want to examine the conditions under which $L$ engages in coordination. In order to prove it we introduce a few definitions and two lemmata. We have to use a more sophisticated definition of what it means to achieve coordination and what constitutes a critical mass than in the main text. We assume that in the absence of coordination the 'minimal' equilibrium occurs. A reasonable notion of 'achieving coordination' is that at least all (and possibly more, for reasons explained below) entrepreneurs in the 'maximal' equilibrium set up a firm. The following propositions will thus focus on achieving (at least) $K^{E M E}$, and the critical mass that enables this. However, we provide a more general definition of critical mass for any equilibrium $K$, and it is straightforward to extend the propositions below to any other equilibrium, using this more general definition of critical mass. 
Critical Mass. Intuitively, a critical mass $M$ relative to some set $K$ is a set $M(K)$ such that conditional on all entrepreneurs in $M(K)$ setting up a firm, all entrepreneurs in $K$ find it profitable to set up a firm. Moreover, $M(K)$ is the smallest such set, i.e., the above property fails to hold if any one entrepreneur is dropped from $M(K)$. For any $K$ there may be several critical masses $M_{s}(K), s=1, \ldots, S$. Note also that $M_{s}(K)$ may be a subset of $K$, contain some elements outside $K$, or it may even be that all elements of $M_{s}(K)$ are outside of $K$. More formally, $M(K)$ is a critical mass for $K$ if it satisfies the following two conditions:

(i) For any set $K^{\prime} \supseteq M(K)$ that satisfies $\pi\left(K^{\prime}, q, r\right) \geq W$ for all $q \in M(K)$ and $\pi\left(K^{\prime}, q, r\right)<W$ for all $q \in Q \backslash K^{\prime}$, it is true that $K^{\prime} \supseteq K$.

(ii) There does not exist any $M^{\prime}(K) \subset M(K)$ that satisfies property (i).

Let $M_{s}(K), s=1, \ldots, S$ be all the critical masses for $K$. We define $M_{\min }(K)$ as the one with fewest elements.

Catalytic Loan Set. A catalytic loan set for $M(K)$ is a set of interest rates $\left\{i_{m}(q)\right\}_{q \in M(K)}$, such that $I_{q}=1$ for all $q \in M(K)$ is the only equilibrium for all entrepreneurs in $M(K)$ when they hold 'pessimistic' beliefs that all entrepreneurs outside of $M(K)$ and $K^{S Q E}$ are not setting up a new firm. We denote a 'catalytic loan set' by $\xi(M)$. The definition of $S Q E$ implies that even with pessimistic beliefs agents assume that all entrepreneurs in $K^{S Q E}$ set up a firm. The above definition also does not require all entrepreneurs in $M(K)$ to have the belief that nobody in $M(K)$ is setting up a firm. Instead it asks for an equilibrium of beliefs for all entrepreneurs in $M(K)$, such as the one we constructed for proposition 2 . Whenever it is not confusing, we will write $M$ instead of $M(K)$.

Our definition of critical mass ensures that even if entrepreneurs initially have beliefs consistent with the $S Q E$, the critical mass can break these beliefs as it forces all remaining equilibria to have the property that at least all entrepreneurs in $K$ set up a new firm. Obviously, there may be more entrepreneurs investing, either as part of $M$ or even outside of $M$ and $K{ }^{41}$ The definition of the critical mass is obviously directly related to the notion of inducing coordination. In particular, $L$ can induce coordination (in the sense of achieving an equilibrium that has all entrepreneurs in $K^{E M E}$ setting up a firm) whenever it mobilizes a critical mass $M\left(K^{E M E}\right)$. We are now ready to state our two lemmata.

\footnotetext{
${ }^{41}$ Our definition of a critical mass is demanding. Starting from the most pessimistic belief, it must be that $K$ is the only equilibrium. If everybody in the economy had an initial belief that some intermediate equilibrium between the minimal and the maximal was being played, then a smaller critical mass would suffice to induce the maximal one. The point we make is that this smaller mass would indeed only work if the initial belief is this intermediate equilibrium. But if it turns out that the initial belief was the minimal, then any "smaller critical mass" will fail to induce coordination to the maximal. By contrast, our critical mass will induce $K$ irrespective of the initial expectations.
} 
Lemma 2 For any critical mass $M(K)$ and any catalytic loan set $\xi(M) L$ makes losses on all entrepreneurs in $M(K)$.

Proof. Since we are dealing with the critical mass for any set $K$ we simply write $M$ instead of $M(K)$. First notice that a necessary-but not sufficient-condition for a set of interest rates to form a catalytic loan set $\xi(M)$ is to make it worth setting up a firm by all entrepreneurs in $M$. Formally, we need that $\beta\left[f\left(K^{S Q E} \cup M, q\right)-\left(1+i_{m}(q)\right) X\right] \geq W$ for all $q \in M$. We prove the lemma by contradiction. Suppose that $L$ makes profits on some $q^{\prime} \in M$, i.e., $i_{m}\left(q^{\prime}\right)>r$ then $\beta\left[f\left(K^{S Q E} \cup M, q^{\prime}\right)-\left(1+i_{m}\left(q^{\prime}\right) X\right] \geq W\right.$ which is equivalent to $f\left(K^{S Q E} \cup M, q^{\prime}\right) \geq\left(1+i_{m}\left(q^{\prime}\right)\right) X+(1+r) E>(1+r) F$. Consider the set $M^{\prime}=M \backslash q^{\prime}$, and suppose that all entrepreneurs in $M^{\prime}$ set up a firm. Then $q^{\prime}$ will also have an incentive to set up a firm, since $\left.f\left(K^{S Q E} \cup M^{\prime}, q^{\prime}\right)=f\left(K^{S Q E} \cup M\right), q^{\prime}\right)>(1+r) F$. But this means that when all entrepreneurs in $M^{\prime}$ set up a firm, also all entrepreneurs in $M$, and so all entrepreneurs in $K$, do set up a firm. In other words, $M^{\prime}$ is a critical mass for $K$. Since $M^{\prime} \subset M$, this contradicts the claim that $M$ is a critical mass.

The intuition of Lemma 1 is that if $L$ were to make profits on any entrepreneur in $M$, then it could drop this entrepreneur, and have her be financed by the fringe investors.

Lemma 3 Consider any equilibrium $K$ for which $L$ finances $M(K)$ with a catalytic loan set $\xi(M(K))$. Then the investors in the competitive fringe finance the $z$ most profitable entrepreneurs of $K \backslash M(K)$.

Proof. The proof consists of showing that $L$ would indeed make lower profits should it choose to compete away some of the most profitable entrepreneurs from the fringe investors. For each $q \in K \backslash M$ define a mapping from $q$ to $\varphi$ such that $f\left(K, \varphi_{1}\right) \geq f\left(K, \varphi_{2}\right) \geq \ldots \geq$ $f\left(K, \varphi_{\|K \backslash M\|}\right)$, where $n=1, \ldots,\|K \backslash M\|$. First suppose that $L$ leaves the financing of the $z$ most profitable entrepreneurs to the investors in the competitive fringe. These investors will maximize their profits by charging the same interest rate $i_{z}$ defined by: $\beta\left[f\left(K, \varphi_{z}\right)-\right.$ $\left.\left(1+i_{z}\right) X\right]=W$ to entrepreneurs $\varphi_{n}, n=1, \ldots, z$. $L$ maximizes its own profits by charging $i_{l}(q)$ such that $\beta\left[f\left(K, \varphi_{n}\right)-\left(1+i_{l}\left(\varphi_{n}\right)\right) X\right]=W$ to entrepreneurs $n=z+1, \ldots,\|K \backslash M\|$. Suppose next $L$ decides to compete for one single entrepreneur $\varphi_{n^{\prime}}$, with $n^{\prime} \leq z$. In this case $L$ has to offer entrepreneur $\varphi_{n^{\prime}}$ the same interest rate (or $\epsilon$ less) than the fringe investors, or else its offer will be refused. The fringe investors now charge $i_{z}$ defined by $\beta\left[f\left(K, \varphi_{z+1}\right)-\right.$ $\left.\left(1+i_{z}\right) X\right]=W$ to entrepreneurs $\varphi_{n}, n=1, \ldots, n^{\prime}-1, n^{\prime}+1, \ldots . z+1 . L$ charges $i_{l}(q)$ satisfying $\beta\left[f\left(K, \varphi_{n}\right)+\left(1+i_{l}\left(\varphi_{n}\right) X\right]=W\right.$ to entrepreneurs $\varphi_{n}, n=z+2, \ldots,\|K \backslash M\|$. Thus $L$ gets the same return on entrepreneurs $n=z+2, \ldots,\|K \backslash M\|$, and finances entrepreneur $\varphi_{n^{\prime}}$ instead of entrepreneur $\varphi_{z+1}$, making zero profits in both cases. As a consequence $L$ is indifferent between competing away one entrepreneur from the fringe or not. Without 
loss of generality we assume it does not. Next, suppose $L$ decides to compete for exactly two entrepreneurs $\varphi_{n^{\prime}}$ and $\varphi_{n^{\prime \prime}}$, with $n^{\prime}<n^{\prime \prime} \leq z$. $L$ must offer these two entrepreneurs the same interest rates (or $\epsilon$ less) than the fringe investor, or else its offers will be refused. The fringe investors now charge $i_{z}$ defined by $\beta\left[f\left(K, \varphi_{z+2}\right)-\left(1+i_{z}\right) X\right]=W$ to all entrepreneurs $\varphi_{n}, n=1, . ., n^{\prime}-1, n^{\prime}+1, \ldots . n^{\prime \prime}-1, n^{\prime \prime}+1, \ldots, z+2 . L$ charges $i_{l}(q)$ satisfying $\beta\left[f\left(K, \varphi_{n}\right)+\right.$ $\left(1+i_{l}\left(\varphi_{n}\right) X\right]=W$ to all entrepreneurs $\varphi_{n}, n=z+3, \ldots,\|K \backslash M\|$. We now ask whether $L$ increases its profits by financing entrepreneurs $n^{\prime}$ and $n^{\prime \prime}$ instead of leaving them to the fringe. By competing, $L$ gets the same return on all entrepreneurs $\varphi_{n}, n=z+3, \ldots,\|K \backslash M\|$, and finances entrepreneurs $n^{\prime}$ and $n^{\prime \prime}$ instead of entrepreneurs $z+1$ and $z+2$. In the former case it receives on both entrepreneurs an interest rate $i_{l}(z+2)$ defined by $\beta\left[f\left(K, \varphi_{z+2}\right)-\right.$ $\left.\left(1+i_{l}(z+2)\right) X\right]=W$. In the latter case it receives a rate $i_{l}(z+1)$ defined by $\beta\left[f\left(K, \varphi_{z+1}\right)-\right.$ $\left.\left(1+i_{l}(z+1)\right) X\right]=W$ on entrepreneur $n^{\prime}$, plus a rate $i_{l}(z+2)$ defined by $\beta\left[f\left(K, \varphi_{z+2}\right)-\right.$ $\left.\left(1+i_{l}(z+2)\right) X\right]=W$ on $n^{\prime \prime}$. $L$ is then clearly worse off when it tries to compete the better entrepreneurs away from the fringe. The same argument applies if $L$ chooses to compete away from the fringe more than two entrepreneurs. We thus conclude that $L$ leaves all the $z$ most profitable entrepreneurs to the fringe.

Suppose now that $L$ is committed to achieving coordination. Denote the equilibrium that results from its optimal choice of a critical mass, given a fringe of size $z$, by $K_{z}^{*}$. Beyond financing a critical mass, $L$ may also finance some more entrepreneurs. We denote the set of these entrepreneurs by $Y$ which satisfies $Y \equiv K_{z}^{*} \backslash\left\{M\left(K_{z}^{*}\right) \cup Z\right\} . L$ makes an overall profit on $Y$ by charging an interest rate $\left.i_{l}(q)\right)$ satisfying $\beta\left[f\left(K_{z}^{*}, q\right)-\left(1+i_{l}(q)\right) X\right]=W$. Assuming $L$ wants to achieve coordination it will maximize:

$$
\rho(z)=\sum_{q \in M}\left(i_{m}(q)-r\right) X+\sum_{q \in Y}\left(i_{l}(q)-r\right) X
$$

by choosing $M\left(K^{E M E}\right), Y, i_{m}(q)$, and $i_{l}(q)$, where $i_{m}(q) \in \xi(M)$. Now define $\widetilde{z} \equiv Q-$ $\left|M_{\min }\left(K^{E M E}\right)\right|$.

Proposition 7 Suppose investors only use pure debt contracts.

(i) Coordination is feasible if and only if $z \leq \tilde{z}$.

(ii) There exists a critical value $\widehat{z}<\widetilde{z}$, such that a necessary condition for $L$ to make profits, and so to induce coordination, is that $z \leq \widehat{z}$.

If $L$ induces coordination:

(iii) it always makes losses on any critical mass $M\left(K^{E M E}\right)$;

(iv) the fringe investors finance the $z$ most profitable entrepreneurs in the set $K_{z}^{*} \backslash M\left(K^{E M E}\right)$, charging them a uniform interest rate $i_{z}$; 
(v) L makes profits on the entrepreneurs in the set $Y$, charging them an interest rate $i_{l}(q)$

(vi) (weakly) more entrepreneurs invest than in the 'maximal' competitive equilibrium. This increases social welfare relative to the 'maximal' competitive equilibrium, although this does not constitute a Pareto-improvement.

Proof. ( $i$ ) If $z$ is larger than $\widetilde{z} \equiv Q-\left\|M_{\min }\right\|, L$ is too small to finance a critical mass, and thus cannot induce coordination.

(ii) The optimal value of $\rho(z)$, denoted by $\rho^{*}(z)$, is a non-increasing function of $z$. This can be seen as follows. Suppose we start with a fringe of size $z_{1}$ and decrease it to $z_{2}<z_{1}$. $L$ can finance those entrepreneurs that were financed by the 'departed' investors $z_{1}-z_{2}$ at the same terms. For $L$ this is feasible, but it may not be optimal. For example, it may manage to charge its new borrowers higher rates than the fringe investors, or it may prefer to finance some other additional entrepreneurs. And since fringe investors make non-negative profits, $L$ cannot decrease its profits by taking over those loans from them. It follows that $\rho^{*}\left(z_{1}\right) \geq \rho^{*}\left(z_{2}\right)$, which proves our claim.

At $z=\left\|K^{E M E}\right\|-\left\|M_{\text {min }}\right\|$ we have $\|Y\|=0$, and so $\rho^{*}(z)<0$ from Lemma 1 . We then define $\widehat{z}$ as the largest (integer) $z$ such that $\rho(z) \geq 0$. Clearly, it must be that $\widehat{z}<$ $\left\|K^{E M E}\right\|-\left\|M_{\min }\right\| \cdot \rho(z) \geq 0$ is however only a necessary condition, since $L$ may prefer to induce some other equilibrium that has not all entrepreneurs in $K^{E M E}$ setting up a firm.

(iii) Follows directly from Lemma 1.

$(i v)-(v)$ Follow directly from Lemma 2.

(vi) If $L$ achieves coordination, then by definition $K_{z}^{*} \supseteq K^{E M E}$. Since all entrepreneurs and investors are making non-negative profits and since there are no negative externalities, it immediately follows that $L$ induces a (weakly) higher level of social welfare than the 'maximal' competitive equilibrium EME. However this does not constitute a Paretoimprovement because entrepreneurs in $Y$ and $Z$ pay a higher interest rate than in the competitive equilibrium.

The final proposition examines how the necessary conditions for investor coordination change when the investors use equity.

Proposition 8 If, in addition to debt, investors can provide finance by taking equity positions:

(i) there exists $\widehat{\widehat{z}}$ with $\widehat{z} \leq \widehat{\vec{z}} \leq Q-\left\|M_{\min }\left(K^{E M E}\right)\right\|$, so that the necessary condition for $L$ to induce coordination can be relaxed to $z \leq \widehat{\widehat{z}}$;

(ii) the cost of financing any critical mass $M$ is reduced;

Suppose the investors hold only equity, then, 
(iii) for a given $W$, there exists $\widehat{F}$ such that $\psi<0$ if and only if $F>\widehat{F}$.

(iv) for a given $F$, there exists $\widehat{W}$ such that $\psi<0$ if and only if $W>\widehat{W}$.

Proof. $(i)-(i i)$ Consider any critical mass $M$ and a catalytic loan $\xi(M)$. We can write $D_{m}(q)=\left(1+i_{m}(q)\right) X$ so that $\beta\left[f\left(K^{p}(q), q\right)-D_{m}(q)\right] \geq W$ for all $q \in M$ and some pessimistic belief $K^{p}$. The pessimistic belief may depend on entrepreneur $q$, in the same manner we described for the chain of expectations in the example of the main text. Then consider any 'catalytic pure equity contract' $\alpha_{m}(q)$ which gives each entrepreneur in $M$ the same return under the pessimistic belief: $\beta\left(1-\alpha_{m}(q)\right) f\left(K^{p}(q), q\right)=\beta\left[f\left(K^{p}(q), q\right)-D_{m}(q)\right]$. Once coordination is achieved we have $f\left(K_{z}^{*}, q\right) \geq f\left(K^{p}(q), q\right)$, so that $\beta\left(1-\alpha_{m}(q)\right) f\left(K_{z}^{*}, q\right) \leq$ $\beta\left[f\left(K_{z}^{*}, q\right)-D_{m}(q)\right]$, and thus $\beta \alpha_{m} f\left(K_{z}^{*}, q\right) \geq \beta D_{m}(q)$. Consequently, $L$ makes higher profits on all the entrepreneurs in $M$, as it can now participate in the value created by its coordination activity.

In equilibrium the fringe investors may undercut $L$ on entrepreneurs in $M$. If $W$ is small enough, then $\alpha$ may be quite large, implying that $L$ is making large profits on some of the entrepreneurs in the critical mass. But as we have seen in the previous section, $L$ prefers not to compete with the fringe for the most profitable entrepreneurs, which may now include some of the entrepreneurs in the critical mass. This, however, does not contradict the analysis since $L$ simply makes neither profit nor loss on these entrepreneurs. This completes the proof for part $(i i)$.

Let $\widehat{\widehat{z}}$ be the maximum size of the competitive fringe when equity financing is possible. It must be that $\widehat{\bar{z}} \geq \widehat{z}$, otherwise $L$ could offer the standard debt contract and still induce coordination at $z=\widehat{z}>\widehat{\widehat{z}}$. To see that $\widehat{\bar{z}}>\widehat{z}$ is possible note that from part (ii) $L$ makes fewer losses on the entrepreneurs in $M$. It may therefore afford to finance fewer entrepreneurs in $Y$ than before, and still have $\rho^{*}(q) \geq 0$. Finally suppose $\widehat{\widehat{z}}>Q-\left\|M_{\text {min }}\right\|$. Then $L$ is too small to finance any critical mass, and the $S Q E$ remains an equilibrium. Thus $\widehat{z} \leq Q-\left\|M_{\min }\right\|$, Moreover, if $M_{\text {min }}$ is not profitable on its own once coordination is achieved then $\widehat{\widehat{z}}<Q-\left\|M_{\text {min }}\right\|$. This completes the proof for part $(i)$.

(iii) Consider any critical mass $M\left(K^{E M E}\right) \subset K^{E M E}$, and a resulting equilibrium $K_{z}^{E M E}$ As before, we have $\rho_{q}=\beta f\left(K_{z}^{E M E}, q\right)-F-W\left(\frac{f\left(K_{\tilde{z}}^{E M E}, q\right)}{f(q, q)}-1\right)$. Summing over all $q \in M\left(K^{E M E}\right)$, we find $\psi=\Xi-M F-W \Sigma$, where $\Xi=\sum_{q=1}^{M} \beta f\left(K_{z}^{E M E}, q\right)$ and $\Sigma=$ $\sum_{q=1}^{M}\left(\frac{f\left(K_{z}^{E M E}, q\right)}{f(q, q)}-1\right)$. We have $\psi<0$ for $F>\widehat{F}=\frac{\Xi}{M}-W \frac{\Sigma}{M}$ and similarly, $\psi<0$ for $E>\widehat{W}=\frac{\Xi-M F}{\Sigma}$.

\section{Proof of Lemma 1}

The first-order condition for the optimal choice of $E_{L}$ is given by $\pi_{2}^{d e}-\frac{(Q-z) E_{z}\left(\pi_{2}^{m}-\pi_{2}^{d i}\right)}{\left(Q-E_{L}\right)^{2}}=0$. The second order condition is always satisfied since $-2 \frac{(Q-z) E_{z}\left(\pi_{2}^{m}-\pi_{2}^{d}\right)}{\left(Q-E_{L}\right)^{3}}<0$. It is useful to 
rewrite the first-order condition as $\theta\left(Q-E_{L}\right)^{2}-(Q-z) E_{z}=0$. If $E_{L}=0$ then this is satisfied at $\theta=\underline{\theta}$. Similarly, if $E_{L}=z$ then this is satisfied at $\theta=\bar{\theta}$. Therefore, for $\theta<\underline{\theta}$, $\theta\left(Q-E_{L}\right)^{2}-(Q-z) E_{z}<0$ for all values of $E_{L}$, so that $E_{L}=0$ is optimal. For $\theta>\bar{\theta}$, $\theta\left(Q-E_{L}\right)^{2}-(Q-z) E_{z}>0$ for all values of $E_{L}$, so that $E_{L}=z$ is optimal. And for $\underline{\theta}<\theta<\bar{\theta}$, we can always find $E_{L} \in(0, z)$, so that $\theta\left(Q-E_{L}\right)^{2}-(Q-z) E_{z}=0$.

\section{Proof of Proposition 4}

Consider $\frac{d E}{d z}=\frac{d E_{z}}{d z}+\frac{\partial E_{I}}{\partial z}+\frac{\partial E_{\perp}}{\partial E_{z}} \frac{d E_{z}}{d z}$. The first effect is simply given by $\frac{d E_{z}}{d z}>0$. The second and third effects depend on $\theta$. For $\theta<\underline{\theta}$, we have a corner solution: $E_{L}=0$, so that $\frac{\partial E_{I}}{\partial z}=0$ and $\frac{\partial E_{I}}{\partial E_{z}} \frac{d E_{z}}{d z}=0$. Both the second and third effect are then zero, so that $\frac{d E}{d z}>0$. For $\theta>\bar{\theta}$, we have $E_{L}=z$, so that $\frac{\partial E_{I}}{\partial z}=1$ and $\frac{\partial E_{I}}{\partial E_{z}} \frac{d E_{z}}{d z}=0$. Now the second effect is positive while the third effect is zero, so that $\frac{d E}{d z}>0$. Finally, for $\underline{\theta}<\theta<\bar{\theta}$, we have $\frac{\partial E_{L}}{\partial z}=\frac{E_{z}}{2 \theta\left(Q-E_{L}\right)}$ and $\frac{\partial E_{L}}{\partial E_{z}}=\operatorname{frac}(Q-z) 2 \theta\left(Q-E_{L}\right)$. The second effect is thus positive, while the third effect is negative. As a result, $\frac{d E}{d z}>0 \Leftrightarrow \frac{d E_{z}}{d z}+\frac{E_{z}}{2 \theta\left(Q-E_{L}\right)}-\frac{(Q-z)}{2 \theta\left(Q-E_{L}\right)} \frac{d E_{z}}{d z}>0$. From the first-order condition we can use $\left(Q-E_{L}\right)=\sqrt{\frac{(Q-z) E_{z}}{\theta}}$ to rewrite the condition as $\frac{d E_{z}}{d z}+\frac{E_{z}}{2 \sqrt{\theta(Q-z) E_{z}}}-\frac{(Q-z)}{2 \sqrt{\theta(Q-z) E_{z}}} \frac{d E_{z}}{d z}>0$. A sufficient condition for this to hold is that the first effect dominates the third effect, i.e. $1>-\frac{(Q-z)}{2 \sqrt{\theta(Q-z) E_{z}}} \Leftrightarrow 4 \theta E_{z}>Q-z$. If this is true at $\theta=\underline{\theta}$, then it is true for all values of $\theta$. It is easy to show that $4 \underline{\theta} E_{z}>Q-z$ is equivalent to $E_{z}>\frac{Q}{2}$. Thus, $E_{z}>\frac{Q}{2}$ is a sufficient condition for $\frac{d E}{d z}>0$. However, it is by no means necessary. Indeed, suppose that $E_{z}<\frac{Q}{2}$, so that there are some values of $\theta$ (in the neighborhood of $\underline{\theta}$ ) where the third effect dominates the first. In this case, all that is required for $\frac{d E}{d z}>0$ to hold is that $\frac{d E_{z}}{d z}$ is small enough, namely that $\frac{d E_{z}}{d z}<$ $\left[\frac{E_{z}}{2 \sqrt{\theta(Q-z) E_{z}}}\right] /\left[\frac{(Q-z)}{2 \sqrt{\theta(Q-z) E_{z}}-1}\right]=\frac{E_{z}}{Q-z-2 \sqrt{\theta(Q-z) E_{z}}}$. If this is satisfied at $\theta=\theta$, then it is satisfied for all values of $\theta$. Finally, it is instructive to examine the special case where fringe banks reinvest their profits at a constant rate $\phi$, so that $E_{z}=z \phi i_{z} X$. After some transformations, we can reduce the above sufficient condition to $E_{z}>\frac{Q}{2} \frac{Q-2 z}{Q-z}$. If this condition is satisfied, then $\frac{d E}{d z}>0$ for all values of $\theta$. But even if it is not satisfied, we still find that $\frac{d E}{d z}>0$ for most values of $\theta$, except in a neighborhood of $\theta=\underline{\theta}$. 


\section{DAVIDSON INSTITUTE WORKING PAPER SERIES - Most Recent Papers}

The entire Working Paper Series may be downloaded free of charge at: www.wdi.bus.umich.edu

CURRENT AS OF 3/7/02

\begin{tabular}{|c|c|c|}
\hline Publication & Authors & Date \\
\hline No. 443: Banks as Catalysts for Industrialization & $\begin{array}{l}\text { Marco Da Rin and Thomas } \\
\text { Hellmann }\end{array}$ & Oct. 2001 \\
\hline $\begin{array}{l}\text { No. 442: Bank-Based or Market-Based Financial Systems: Which is } \\
\text { Better? }\end{array}$ & Ross Levine & Feb. 2002 \\
\hline $\begin{array}{l}\text { No. 441: Migration and Regional Adjustment and Asymmetric Shocks } \\
\text { in Transition Economies }\end{array}$ & Jan Fidrmuc & Feb. 2002 \\
\hline $\begin{array}{l}\text { No. 440: Employment and Wages in Enterprises Under Communism } \\
\text { and in Transition: Evidence From Central Europe and Russia }\end{array}$ & $\begin{array}{l}\text { Swati Basu, Saul Estrin, and Jan } \\
\text { Svejnar }\end{array}$ & June 2000 \\
\hline No. 439: Small business in Russia: A Case Study of St. Petersburg & Alessandro Kihlgren & Jan. 2002 \\
\hline $\begin{array}{l}\text { No. 438: Foreign Direct Investment as Technology Transferred: } \\
\text { Some Panel Evidence from the Transition Economies }\end{array}$ & $\begin{array}{l}\text { Nauro F. Campos and Yuko } \\
\text { Kinoshita }\end{array}$ & Jan. 2002 \\
\hline No. 437: Whistleblowing, MNC's and Peace & Terry Morehead Dworkin & Feb. 2002 \\
\hline $\begin{array}{l}\text { No. 436: A Note on Measuring the Unofficial Economy in the Former } \\
\text { Soviet Republics }\end{array}$ & $\begin{array}{l}\text { Michael Alexeev and William } \\
\text { Pyle }\end{array}$ & Sept. 2001 \\
\hline $\begin{array}{l}\text { No. 435: The Ownership School vs. the Management School of State } \\
\text { Enterprise Reform: Evidence from China }\end{array}$ & David D. Li and Changqi Wu & Jan. 2002 \\
\hline $\begin{array}{l}\text { No. 434: The Effect of Ownership and Competitive Pressure on Firm } \\
\text { Performance in Transition Countries: Micro Evidence from Bulgaria, } \\
\text { Romania and Poland. }\end{array}$ & $\begin{array}{l}\text { Manuela Angelucci, Saul Estrin, } \\
\text { Jozef Konings, Zbigniew } \\
\text { Zolkiewski }\end{array}$ & Jan. 2002 \\
\hline No. 433: The End of Moderate Inflation in Three Transition Economies? & Josef C. Brada and Ali M. Kutan & Jan. 2002 \\
\hline $\begin{array}{l}\text { No. 432: What Drives the Speed of Job Reallocation During Episodes of } \\
\text { Massive Adjustment? }\end{array}$ & $\begin{array}{l}\text { Stepan Jurajda and Katherine } \\
\text { Terrell }\end{array}$ & Jan. 2002 \\
\hline $\begin{array}{l}\text { No. } 431 \text { Forthcoming in: The Journal of Economic Perspectives, } \\
\text { "Competition and Corporate Governance in Transition," 16(2) Feb. } \\
\text { 2002. }\end{array}$ & Saul Estrin & Dec. 2001 \\
\hline $\begin{array}{l}\text { No. 430: Corporate Governance in the Cause of Peace: An } \\
\text { Environmental Perspective }\end{array}$ & Don Mayer & Jan. 2002 \\
\hline No. 429: Why do Governments Privatize? & $\begin{array}{l}\text { Loren Brandt, Hongbin Li, and } \\
\text { Joanne Roberts }\end{array}$ & Dec. 2001 \\
\hline No. 428: Testing Russia's Virtual Economy & Vlad Ivanenko & Dec. 2001 \\
\hline No. 427: War and the Business Corporation & Eric W. Orts & Dec. 2001 \\
\hline $\begin{array}{l}\text { No. 426: Partial Privatization and Firm Performance: Evidence from } \\
\text { India }\end{array}$ & Nandini Gupta & Dec. 2001 \\
\hline $\begin{array}{l}\text { No. 425: Direct Foreign Investments and Productivity Growth in } \\
\text { Hungarian Firms, 1992-1999 }\end{array}$ & Jérôme Sgard & Nov. 2001 \\
\hline $\begin{array}{l}\text { No. 424: Banking Passivity and Regulatory Failure in Emerging } \\
\text { Markets: Theory and Evidence from the Czech republic. }\end{array}$ & Jan Hanousek and Gerard Roland & July 2001 \\
\hline $\begin{array}{l}\text { No. 423: Conceptions of the Corporation and the Prospects of } \\
\text { Sustainable Peace }\end{array}$ & Jeffrey Nesteruk & Dec. 2001 \\
\hline No. 422: The Role of the Corporation in Fostering Sustainable Peace & Timothy Fort and Cindy Schipani & Nov. 2001 \\
\hline No. 421: Wage Arrears and the Distribution of Earnings in Russia & $\begin{array}{l}\text { Hartmut Lehmann and Jonathan } \\
\text { Wadsworth }\end{array}$ & Dec. 2001 \\
\hline $\begin{array}{l}\text { No. 420: Transferring Collective Knowledge: Collective and } \\
\text { Fragmented Teaching and Learning in the Chinese Auto Industry }\end{array}$ & $\begin{array}{l}\text { Jane Zhou, Jaideep Anand, and } \\
\text { Will Mitchell }\end{array}$ & Dec. 2001 \\
\hline $\begin{array}{l}\text { No. 419: Liberalization, Corporate Governance, and the Performance of } \\
\text { Newly Privatized Firms }\end{array}$ & $\begin{array}{l}\text { Narjess Boubakri, Jean-Claude } \\
\text { Cosset, and Omrane Guedhami }\end{array}$ & Dec. 2001 \\
\hline $\begin{array}{l}\text { No. 418: The European Data Privacy Directive and International } \\
\text { Relations }\end{array}$ & Steven R. Salbu & Dec. 2001 \\
\hline
\end{tabular}

